\title{
AUTHORITARIAN INTERNATIONAL LAW?
}

\author{
By Tom Ginsburg
}

\section{ABSTRACT}

International law, though formally neutral among regime types, has mainly been a product of liberal democracies since World War II. In light of recent challenges to the liberal international order, this Article asks, what would international law look like in an increasingly authoritarian world? As compared with democratic countries, authoritarians emphasize looser cooperation, negotiated settlements, and rules that reinforce regime survival. This raises the possibility of authoritarian international law, designed to extend authoritarian rule across time and space.

It is no secret that liberal democracy is in trouble around the world. The number of democracies in the world peaked around 2006, and has declined in each year since then. Some young democracies have been lost, and even long-established democracies have seen erosion in the quality of democratic institutions. There is a small cottage industry of books and articles lamenting democracy's decline, and the most recent version of the well-known Freedom in the World report is subtitled Democracy in Crisis. ${ }^{1}$ More broadly, the global liberal order is under assault from populists, economic nationalists, and autocrats. Human rights, too, has been eulogized in a series of recent books on the "twilight" or "endtimes" of human rights. ${ }^{2}$

To be sure, the situation could change, and there are several recent examples of jurisdictions that reversed their slippage toward autocracy. ${ }^{3}$ From Armenia to Malaysia, it seems a bit too soon to count on the inevitable death of democracy. But there are also long term trends that cut in the other direction. Western democracies dominated the global economy for much of the 1990s, producing well over half of world gross domestic product. However, at some point in the next five years, some believe that the total share of global output produced by

* Leo Spitz Professor of International Law, Ludwig and Hilde Wolf Research Scholar, Professor of Political Science, University of Chicago Law School. For helpful discussions and comments, thanks to Bojan Bugaric, Adam Chilton, Sannoy Das, Jeffrey Dunoff, Matthew Erie, PY Lo, Richard McAdams, Sarah Nouwen, Eric Posner, Wei Shen, Spencer Smith, Pierre-Hugues Verdier, and the audiences at the Lauterpacht Centre for International Law at Cambridge University, where some of this material was presented as part of the Hersch Lauterpacht Memorial Lectures in March 2019, as well as the Pluricourts Center at Oslo University. For research assistance, thanks to Shivani Agarwal, Marie Elisabeth Beudels, Yingxin Chen, Alex Kong, Ana Luquerna, Bhavana Resmi and Michelle Ullman. Special thanks to the Board of Editors of this Journal, whose tough comments improved the piece significantly.

${ }^{1}$ David Runciman, How Democracy Ends (2018); Steven Levitsky \& Daniel Ziblatt, How Democracies Die (2018); Michael J. Abramowitz, Freedom in the World 2018: Democracy in Crisis, Freedom House (2018). This followed the 2017 Freedom House report which was subtitled Democracy Beleaguered.

${ }^{2}$ Stephen Hopgood, The Endtimes of Human Rights (2013); Eric Posner, The Twilight of Human Rights Law (2014); Costas Douzinas, The End of Human Rights (2000).

3 Tom Ginsburg \& Aziz Z. Huq, Democracy's Near Misses, 29 J. Democ. 16 (2018). 
dictatorships will surpass that of the Western democracies, which will fall to less than a third. ${ }^{4}$ China is now a major source of outbound capital, and the world's largest official creditor. ${ }^{5}$ With less than half the world's population now living in nations that are fully or even "flawed" democracies, there is a strong possibility that the twenty-first century will be known more as an authoritarian century than a democratic one. These trends suggest that it is worth trying to understand what impact rising authoritarianism will have on international law.

There are three major features of today's authoritarian regimes that are important to understand, in contrast with previous eras. First, today's dictatorships are for the most part integrated into the global capitalist economy, and so rely heavily on international trade, labor, and investment flows. An autocratic country is not an autarkic one. This means that there will be continuing demand for some regional and global public goods from dictatorships and democracies alike, especially in the economic sphere. Relatedly, uniform market regulations benefit all, and regulatory power is as important for markets as military power is for security. ${ }^{6}$ Battles over global regulation, which have heretofore been fought mainly between the United States and the European Union, will now involve China and perhaps other nondemocratic countries to a greater degree.

A second feature is the relative decline of ideology. To be sure, there are some authoritarians that rely heavily on ideological rhetoric, such as Venezuela under Nicolas Maduro or theocratic Iran. But the powerful appeal of global communism or political Islam are largely things of the past, and many authoritarian regimes are driven more by a desire for political survival than a consistent ideological message. In the new "marketplace of political change" authoritarians are increasingly assertive, but less ideologically motivated, relative to earlier eras. ${ }^{7}$

Another major feature of our time is the abuse of democratic forms for anti-democratic purposes. Many of today's authoritarians have constitutions with long lists of rights, which in form are scarcely distinguishable from those found in democratic orders. ${ }^{8}$ They have courts that are structurally independent, with genuine power over certain realms of activity. They hold regular elections, and have nominally independent accountability bodies. But these institutions function in completely different ways than they do in democracies. Instead of facilitating the turnover of leaders, elections in authoritarian regimes are designed to elicit information and consent from the public, so as to extend the political lives of leaders. ${ }^{9}$ Instead of providing a check on the ruler, courts are designed to support market transactions and discipline low-level administrative agents, but not hold the core power itself accountable. ${ }^{10}$ In some cases, courts become an instrument of rulers, and we have recently seen several

\footnotetext{
${ }^{4}$ Roberto Stefan Foa \& Yascha Mounck, When Democracy Is No Longer the Only Path to Prosperity, WaLl ST. J., March 1, 2019, at C4. This statistic likely excludes Japan, Korea, and Taiwan from the ranks of "Western" democracies and is conducted on a Purchasing Power Parity (PPP) basis.

${ }^{5}$ United Nations Conference on Trade and Development, UNCTAD Stat, at http://unctadstat.unctad.org/wds/ ReportFolders/reportFolders.aspx?sCS_ChosenLang=en.

${ }^{6}$ Anu Bradford, The Brussels Effect: How the European Union Rules the World (2020).

7 Thomas Carothers \& Oren Samet-Marram, The New Global Marketplace of Political Changes, CARnEGIE Endowment InT'L Peace (Apr. 2015).

${ }^{8}$ Zachary Elkins, Tom Ginsburg \& James Melton, The Content of Authoritarian Constitutions, in Constitutions in Authoritarian Regimes 141 (Tom Ginsburg \& Alberto Simpser eds., 2014).

${ }^{9}$ Jennifer Gandhi, Political Institutions Under Dictatorship (2008).

10 Tamir Moustafa, The Struggle for Constitutional Power: Law, Politics, and Economic DeVElopment In Egypt (2007).
} 
instances in which national high courts have relied on international law to help leaders extend their terms of office beyond what the constitutions allowed. ${ }^{11}$ Constitutions in such countries are not designed to limit power but rather to exhort the people toward ideological goals, or to provide for formal institutions that do not operate as the real arena of power. ${ }^{12}$ As scholars have analyzed how nominally democratic institutions benefit dictators, they have deepened our understanding of those institutions, in terms of their strengths and vulnerabilities. ${ }^{13}$

In this spirit, this Article introduces the concept of authoritarian international law, documents some nascent features, and speculates on its trajectory. Today's authoritarian regimes are increasingly facile in their engagement with international legal norms and institutions, deploying legal arguments with greater acuity, even as they introduce new forms of repression that are legally and technologically sophisticated. ${ }^{14}$

Of course, in the long view, international law has always been amenable and even facilitative of authoritarian governance. The Congress of Vienna codified a conservative restoration to head off republican mobilization in the aftermath of the French Revolution. Colonialism and imperialism were blessed by supportive international legal doctrines. ${ }^{15}$ "Proletarian internationalism" emphasized a distinct set of international legal principles. ${ }^{16}$ Both the United States and Soviet Union used international law to justify their respective support of authoritarian regimes during the Cold War. But both intellectually and practically, the post-World War II era of international law was dominated by Western, mainly democratic nations. ${ }^{17}$ This led to a distinct set of norms and institutions, which balanced traditional concerns about sovereignty with liberal notions of human rights and political participation.

The end of the Cold War marked a new era in which this balance seemed to shift in the direction of liberalism. Generalizing from the experience of Europe, scholars proclaimed a new era of "liberal international law" as regional and multilateral organizations expanded rapidly, and supranational adjudication increased in substantive scope and geographic reach. ${ }^{18}$ The core idea-that international law was qualitatively different and more effective among liberal states - was well-suited to the general mood that liberalism would inevitably expand, and that international law should support this development.

This era is now decidedly over, and we may be returning to an era in which international law is facilitative of authoritarian governance. Many of those authoritarian regimes that survived the liberal wave of the 1990s did so in part because they were embedded in a global

${ }^{11}$ David Landau, Rosalind Dixon \& Yaniv Roznai, From an Unconstitutional Constitutional Amendment to an Unconstitutional Constitution? Lessons from Honduras, 8 GLob. Constitutionalism 40, 45 (2019). Tribunal Constitucional Plurinacional, Sentencia Constitutional Plurinacional No. 0084/2017, Nov. 28, 2017, at 5 (Bol.); Supreme Court of Justice, Constitutional Chamber, Decision of Apr. 22, 2015, cited in Landau, Dixon \& Roznai at n. 47, available at http://www.poderjudicial.gob.hn/Documents/FalloSCONS23042015.pdf.

${ }^{12}$ Constitutions in Authoritarian Regimes (Tom Ginsburg \& Alberto Simpser eds., 2014).

${ }^{13}$ Ae Sil Woo \& Courtenay R. Conrad, The Differential Effects of "Democratic" Institutions on Dissent in Dictatorships, 81 J. Pol. 456 (2019); Gandhi, supra note 9; Milan Svolik, The Politics of Authoritarian RULE (2014).

${ }^{14}$ See Taisu Zhang \& Tom Ginsburg, China's Turn Toward Law, 59 VA J. InT'L L 307 (2019).

${ }^{15}$ Anthony Anghie, Imperialism, Sovereignty, and the Making of International Law (2005).

16 William E. Butler, "Socialist International Law" or "Socialist Principles of International Relations"?, 65 AJIL 796 (1971).

17 See, e.g., Anthea Roberts, Is International LaW International? (2017).

${ }^{18}$ Anne Marie Slaughter, International Law in a World of Liberal States, 6 Eur. J. INT'L L. 503 (1995); see also Karen Alter, The New Terrain of International Law: Courts, Politics, Rights (2014) (on adjudication). 
capitalist economy, itself underpinned by international legal institutions, that provided new resources for regime survival. What is distinct about our era relative to earlier ones is the way in which authoritarians are using international law, building on and repurposing some of the norms of the liberal era, but to very different ends. This Article speculates that these developments may end up shaping international law itself, at least for a large number of states.

As a threshold matter, I adopt a working definition of democracy and authoritarianism. Democracy, of course, is an "essentially contested concept"19 for which there are nearly as many definitions as there are analysts. In a recent book, Aziz Z. Huq and I provide a relatively thin definition with three components: elections; a small set of core rights related to political contestation such as rights to free speech, association, and voting; and the rule of law, especially as applied to electoral contestation. ${ }^{20}$ This seems to be a workable definition for thinking about pro- and anti-democratic behavior that crosses borders. Activity that seeks to enhance freedoms of speech and association, and that promotes electoral integrity, is pro-democratic, while activity directed at suppressing those things is pro-authoritarian. ${ }^{21}$

Authoritarian regimes are incredibly diverse as a group. The category includes royal dictatorships, military juntas, and people's republics. Increasingly, we see states like Venezuela, Hungary, or Turkey, which hold elections, but an elected leader undermines the rule of law and the core rights of speech and association. Many of today's populist regimes hover near the boundary. But for purposes of this Article, they can be considered authoritarian, particularly if they utilize international law in ways that seek to undermine democratic governance as defined above. In this aspect, at least, they are not visibly different from traditional authoritarians.

The Article proceeds as follows. After introducing the concept of authoritarian international law in Part I, Part II lays out a theory about the differential use of international law by authoritarians and democrats. Part III then provides evidence to show that, consistent with the claims of many critics, international law during the post-World War II era has been by and large a product of democracies. This part uses large-n empirical methods, drawing a binary between authoritarian and democratic regimes. Such binaries are obviously simplifications, but useful for analytic purposes. Part IV turns to the main part of the Article, tracing the evolution of how authoritarian countries have sought to cooperate across borders by examining several important historical examples: the Warsaw Pact, the Association of Southeast Asian Nations (ASEAN), the Eurasian Economic Community, and the Shanghai Cooperation Organization. I focus on regional organizations, which have served as sites for gradual learning and experimentation. Part $\mathrm{V}$ then provides examples of how authoritarian regimes might change the normative content of international law itself, diluting democratic

${ }^{19}$ John S. Dryzek, Can There Be a Human Right to an Essentially Contested Concept: The Case of Democracy, 78 J. Pol. 357, 358-59 (2016); W. B. Gallie, Essentially Contested Concepts, 56 Proc. Aristotelian Soc. 167 (1956).

${ }^{20}$ Tom Ginsburg \& Aziz Z. HuQ, How to Save a Constitutional Democracy 9 (2018); see also David Collier \& Steven Levitsky, Democracy with Adjectives: Conceptual Innovation in Comparative Research, 49 WORLD POL. 430 (1997). For some purposes in this Article, I will also examine numeric indicators of democracy that draw on other conceptualizations. However, little turns on the precise definition for the rough statistical analyses I provide, since there is a good deal of agreement across indicators about which countries are democratic and which are not.

${ }^{21}$ Martin Elff \& Sebastian Ziaja, Methods Factors in Democracy Indicators, 6 PoL. \& Gov. 92 (2018); Jan Teorell, Michael Coppedge, Svend-Erik Skaaning \& Staffan I. Lindberg, Measuring Electoral Democracy with V-Dem Data: Introducing a New Polyarchy Index (Varieties of Democracy Working Paper Series, 2016(25)). 
norms and developing some of their own. This last feature, what I label "authoritarian international law," is designed to extend authoritarian rule across time and space. Parts VI and VII speculate on future developments and conclude.

The changes this Article describes are not epochal, but subtle, and involve layering on existing norms and institutions. To preview the major findings, rising authoritarianism will produce shifts within existing international law structures, including the continued decline of human rights enforcement, although perhaps with more innovation in and commitment to international economic law. ${ }^{22}$ Authoritarians have always had more use for international economic law than for rules that hamper flexibility in the political or security spheres. We may also see less use of formal third-party adjudication, and more emphasis on state-to-state negotiation and diplomacy as preferred mechanisms for resolving disputes. Finally, a greater role for authoritarians will likely accelerate long-term trends toward executive power within national constitutional orders, perhaps providing feedback effects that encourage yet more authoritarian governments. The result may be a more stable set of authoritarian regimes, interacting across borders to repress each other's opponents, with less room for international human rights or democracy promotion. This will eventually lead to the development of new norms and practices.

A word is in order about the use of evidence drawn from regional institutions. With global treaty-making at something of a standstill, we have seen a rise in regional cooperation in trade, investment, and human rights. ${ }^{23}$ These institutions interact and cross-fertilize, with norms spreading across regions. As will be documented below, authoritarians have been increasingly creative in using regional organizations to develop new norms and to cooperate for defensive purposes. Regional law is thus a good place to look for new developments that might ultimately influence broader international norms. But it also means that the developments described here could end up being limited to particular regions or subsets of countries. Indeed, many of the claims about liberal international law were drawn from the experience of Europe. ${ }^{24}$ Authoritarian international law, like liberal international law before it, might end up being only one element at work in the broader international legal system. ${ }^{25}$ Nevertheless, the central claim of this Article is that this illiberal sphere is growing, potentially transformative, and normatively troubling.

\section{Conceptualizing Authoritarian International Law}

It is useful to begin by restating the classical view of the international legal system as facilitating ideological pluralism. While the United Nations Charter speaks of protecting fundamental human rights, it also provides for self-determination and limits the United Nations from intervening in matters "essentially within the domestic jurisdiction

\footnotetext{
${ }^{22}$ China Disappointed Over WTO Appellate Body Impasse, Calling for Justice in International Community, XinHUANeT (Dec. 11. 2019), at http://www.xinhuanet.com/english/2019-12/11/c_138623696.htm.

${ }^{23}$ Mathias Forteau, Regional International Law, in Max Planck EnCyClopedia of Public International LaW (2006).

${ }^{24}$ Anne Marie Slaughter \& William W. Burke-White, The Future of International Law Is Domestic (Or, the European Way of Law), 47 HARV. INT'L L.J. 327 (2006).

${ }^{25}$ This is consistent with Andrew Moravcsik, Liberal Theories of International Law, in INTERDISCIPLINARY Perspectives on International Law and International Relations: The State of the Art 83 (Jeffrey L. Dunoff \& Mark A. Pollack eds., 2012).
} 
of any state." 26 These two competing imperatives create internal tensions in the Charter, but the basic idea is that, so long as certain minimal and loosely defined standards are met, international law demands agnosticism about regime type. The central purpose of international law is not to facilitate the spread of any particular form of government but instead to facilitate the interactions of governments of very different types. From this point of view, "International law has no life of its own, has no special normative authority; it is just the working out of relations among states, as they deal with relatively discrete problems of international cooperation." ${ }^{27}$ International law, in essence, is neither democratic nor authoritarian, moral nor immoral, good nor bad.

This classical view has been challenged by many critics; for present purposes, the most important are scholars who have sought to deploy international law in the service of democracy. To briefly recap that literature, in 1992, just after the end of the Cold War, Thomas Franck identified what he called an "emerging" right to democratic governance. ${ }^{28}$ In an era of high optimism about the prospects of democracy, Franck bundled a provocative doctrinal claim with a positive prediction about the future trajectory of international law, generating a serious and important debate. ${ }^{29}$ Franck grounded his right to democratic governance on three separate pillars: the right to self-determination, which dated from the Wilsonian era; rights to freedom of expression and association, embodied in the postwar human rights architecture; and rights to political participation through elections, which he saw being implemented at the time of his writing. The expanding number of democracies provided evidence, in his view, of state practice constructing a legal norm. "Both textually and in practice," his article concluded, "the international system is moving toward a clearly designated democratic entitlement, with national governance validated by international standards and systematic monitoring of compliance. The task is to perfect what has been so wondrously begun."30

Franck has been attacked on various grounds, prominently in a 2000 edited volume, Democratic Governance and International Law. ${ }^{31}$ One powerful line of thought, associated with Professor Brad Roth, has consistently defended the international arena as one of ideological pluralism, in which a right to democracy could be destabilizing, and in which societies ought to be free to subordinate the democratic entitlement to other

${ }^{26}$ UN Charter, Art. 2(7).

${ }^{27}$ Jack Goldsmith \& Eric Posner, The Limits of International Law, AEI BooK Summary 2 (April 2005); see generally Jack Goldsmith \& ERIC Posner, The Limits of International Law (2005)

${ }^{28}$ Thomas M. Franck, The Emerging Right to Democratic Governance, 86 AJIL 46 (1992); see also Fernando R. Tesón, Two Mistakes About Democracy, 92 ASIL Proc. 126 (1998); Fernando R. Tesón, The Kantian Theory of International Law, 92 Colum. L. Rev. 53 (1992).

${ }^{29}$ James Crawford, Democracy and International Law, 64 Brit. Y.B. InT'L L. 113 (1994); Democratic Governance and International Law (Gregory H. Fox \& Brad Roth eds., 2000); Susan Marks, What Has Become of the Emerging Right to Democratic Governance?, 22 EuR. J. InT'L L. 507 (2011); J.H.H. Weiler, The Geology of International Law-Governance, Democracy and Legitimacy, 64 ZAöRV [HeIDelberG J. InT'L L.) 547 (2004).

${ }^{30}$ Franck, supra note 28 , at 91 .

${ }^{31}$ Fox \& Roth, supra note 29; Gregory H. Fox \& Brad Roth, The Dual Lives of "The Emerging Right to Democratic Governance," 112 AJIL Unbound 67 (2018); Marks, supra note 29; DemOCRACY AND International Law (Richard Burchill ed., 2006); Same Varayudej, A Right to Democracy in International Law: Its Implications for Asia, 12 ANN. SuRv. INT'L COMP. L (2006), available at http://digitalcommons.law.ggu.edu/ annlsurvey/vol12/iss $1 / 2$. 
collective goals. ${ }^{32}$ By turning democracy itself into a right, Franck conflated the two and puts a good deal of pressure on cosmopolitan institutions, leaving less space for democratic choice. As put succinctly by John Dryzek, if democracy were to be accepted as a universal legal right, there would be disruptive implications for international order, "for non-democratic states would become illegitimate members of the international community." 33 Pro-democratic military intervention would then become routine, undermining the pluralist vision of international law. Indeed, this is precisely the critique that has been leveled against American foreign policy in the aftermath of the Cold War: liberal hegemony led to overreach and conflict with other great powers. ${ }^{34}$

Another argument that liberalism has become instantiated in international law is the claim, put forward by cosmopolitans, that the foundation of international law itself relies on individual freedom and dignity. Whether a "cosmopolitan legal order" or the exercise of "legitimate public authority," scholars working in this Kantian vein argue that the very purpose of cooperation is to advance human dignity. ${ }^{35}$ Many of these scholars emphasize regional (especially European) arrangements as sites of liberal transnationalism. Regionalism, though, can also be used for illiberal cooperation, and this Article will provide several examples.

Let me now clarify terms. What do I mean by authoritarian international law? As Ian Hurd puts it in his superb recent book, international law allows states to "do things" that they could not accomplish without it, namely the production of public goods across borders. ${ }^{36}$ The things that are done with international law need not be necessarily pro- or anti-democratic. One might define authoritarian international law as simply international legal interactions among authoritarian states. But as I will briefly document below, as a general matter authoritarian states do not seem to participate in the international legal order to the same degree as democracies. Democracies, it turns out, are much more likely than autocracies to conclude treaties, to litigate cases before international tribunals, and to engage in international lawmaking bodies. ${ }^{37}$ Even if authoritarians and democrats were "doing the same things" with international law, democracies would have more impact by virtue of their more intensive interactions with the system. Much of what we have come to think of as general international law, it turns out, is the product of democratically elected governments. ${ }^{38}$

This does not, however, make most international law inherently democratic. Instead, I define pro-democratic international law as the category emphasized by Franck: the things that democracies do with international law are designed to protect and extend the sphere of democratic governance. Examples include human rights agreements that enshrine

\footnotetext{
${ }^{32}$ Brad Roth, Sovereign Equality and Moral Disagreement: Premises of a Pluralist International Legal Order (2011).

33 Dryzek, supra note 19 , at 358.

${ }^{34}$ John J. Mearsheimer, The Great Delusion: Liberal Dreams and International Realities (2018).

${ }^{35}$ Alec Stone Sweet \& Clare Ryan, A Cosmopolitan Legal Order (2018); Matthias Kumm, An Integrative Theory of Global Public Law: Cosmopolitan, Pluralist, Public Reason Oriented (manuscript on file with author); InTERnATIONAL JUdicial LaWMaking (Armin von Bogdandy \& Ingo Venzke eds., 2012); Transformative Constitutionalism in Latin America: Emergence of a New Ius Commune (Armin von Bogdandy, Eduardo Ferrer Mac-Gregor, Mariela Morales Antoniazzi, Flávia Piovesan \& Ximena Soley eds., 2017).

36 Ian Hurd, How to Do Things with InTERnational Law (2017).

37 These facts are summarized briefly below.

38 Shirley V. Scott, The Decline of International Law as a Normative Ideal., 49 Victoria Univ. WeLLINGTON L. REV. 627 (2018).
} 
democratic participation and core civil rights, democracy charters of regional organizations, and election monitoring. ${ }^{39}$ But much international legal behavior by democratic governments does not have this specific character. Indeed, we know that democracies are perfectly happy to collaborate with authoritarian regimes, should economic or political motives so dictate. ${ }^{40}$ Conversely, the mere fact that authoritarian regimes engage in certain kinds of international behavior does not itself make that behavior authoritarian in any qualitative sense. I argue that much of what authoritarians are doing is returning us to a world of Westphalian international law, primarily as a defensive measure.

But that does not mean that authoritarians will be content with Westphalian neutrality. In an interdependent world of cyberattacks, election interference, and transborder investment by state-owned entities, noninterference is more myth than reality. We should anticipate the possibility of a specifically authoritarian international law, defined as legal rhetoric, practices, and rules specifically designed to extend the survival and reach of authoritarian rule across space and/or time. Such a pro-authoritarian approach would give us three categories of international law: pro-democratic, general or regime-neutral, and authoritarian.

\section{Theory: Why Would Authoritarians Be Different?}

The starting point of this Article's theory is the logic of regime survival, a well-known theory in political science. ${ }^{41}$ The assumption is that all leaders, regardless of the political system they operate in, seek to survive in office. To do so, they must provide some goods for enough of their citizens to retain power; the key differences between democracy and dictatorship lie in the size of the relevant group of beneficiaries, and the availability of information within the country. Democrats must satisfy a majority of voters, and can be monitored by their constituents with relative ease. ${ }^{42}$ The set of people who "matter" is larger, even as large as a majority of the electorate. In a dictatorship, in contrast, the set of people who matter is smaller. It still may be a very large group - the Chinese Communist Party, for example, has nearly ninety million members at this writing. But it never approaches a majority of the society. Furthermore, to maintain power, authoritarians must manipulate information about decision making and performance.

Why should any government interested in its own survival cooperate internationally? The standard answer is that some public goods, by their very nature, cannot be produced within the borders of a single country. Two countries that share a river, for example, will not be able to manage it unless they cooperate; a set of countries interested in regional security or defense against a mutual enemy can do so by creating regional organizations that can coordinate action. Market access, too, can be helpful for some kinds of governments, particularly if they are developmental regimes with a capitalist orientation. Cooperation brings benefits, while imposing some costs in loss of control.

\footnotetext{
39 See, e.g., African Charter on Democracy, Elections and Governance (2007); Inter-American Democratic Charter (2001). See Ben Kioko, The African Charter on Democracy, Elections and Governance as a Justiciable Instrument, 63 S1 J. African L. 39 (2019).

${ }^{40}$ Toke Aidt \& Facundo Albornoz, Political Regimes and Foreign Intervention. 94 J. Dev't Econ. 192 (2011).

${ }^{41}$ Bruce Bueno de Mesquita \& Alastair Smith, The Dictator's Handbook: Why Bad Behavior Is Almost Always Good Politics (2012).

42 In emphasizing information, I am drawing on a literature in international relations. Xinyuan Dai, Why Comply? The Domestic Constituency Mechanism, 59 InT'L Org. 363 (2005).
} 
In thinking about whether or not to cooperate on international public goods, democracies and dictatorships may be differently situated, both with regard to propensity and type. While larger markets and access to capital may be attractive to all kinds of governments (especially for smaller states), there are some authoritarian regimes which do not desire these things for ideological reasons, ${ }^{43}$ and others that might fear the risk of alternative power centers through open markets. Authoritarians tend to prefer segmentable public goods ("club goods") that can be delivered to their supporters and withheld from opponents. ${ }^{44}$ Conversely, democrats may be more likely to support human rights protection and democracy promotion as global public goods, worthy of multilateral and cross-national cooperation. Such a view might make sense for material reasons - democracies tend to trade with each other and do not go to war against each other-or for ideological ones.

Besides different issues for cooperation, time horizons and transparency also differ across regime types. In a properly functioning democratic system, time horizons are long. Democracy's survival depends on the prediction that the regime of elections will continue, even if the governing party loses power. ${ }^{45}$ If a party thinks elections are unlikely to continue, it will not turn over office after a loss. Thus in a democracy, regime survival and government survival are by definition different: government termination depends on the prospect of regime endurance. Political parties are important here, for they extend the time horizons of politicians beyond their immediate lifetime, and can survive even when out of power. Democracy endures while its governments are finite. This generates a desire for institutions - including international law - that can commit the state beyond the life of the current government. Enduring commitment facilitates democracy because it reduces the stakes of electoral loss. ${ }^{46}$

In contrast, in many dictatorships, regime survival and government survival are the same. Authoritarians fear revolution from below, but also displacement from other members of the elite, the most common way that authoritarians exit office. ${ }^{47}$ The result is that authoritarians see the survival of their government as coextensive with regime survival. Of course there are ways of extending government survival across generations: If the regime is a monarchy, the leader's descendants will extend her government into the future, and this prospect in turn may induce better governance in the present. Even nonmonarchies can have clear succession rules, as did the Chinese Communist Party from roughly 1979 until 2018. But regime survival and government survival are essentially the same, at least in the eyes of the leaders. Authoritarian leaders' "discount rate," in turn, will reflect this identity: they will desire only those forms of international cooperation that will help the government survive.

\footnotetext{
${ }^{43}$ Cuba and North Korea might be the last remaining examples here. The Bolivarian states of Latin America did adopt a People's Trade Agreement dedicated to fair and balanced trade in the service of the "higher interests of development of the peoples." See SELA, The Bolivarian Alliance for the Peoples of Our America - Peoples' Trade Agreement (ALBA-TCP) (2015), SP/CL/XLI.O/Di No. 11-15, available at http://s017.sela.org/media/2087752/ di-11-alba-tcp-ing.pdf.

${ }^{44}$ Michael Albertus \& Victor Menaldo, Authoritarianism and the Elite Origins of Democracy (2018).

45 Adam Przeworski, Crises of Democracy 5 (2019).

${ }^{46}$ Stephen Holmes, Passions and Constraint: On the Theory of Liberal Democracy 134-77 (1995).

${ }^{47}$ Milan Svolik, The Politics of Authoritarian Rule (2012); Barbara Geddes, Stages of Development in Authoritarian Regimes, in World Order After Leninism (Vladimir Tismaneanu, Marc Morjé Howard \& Rudra Sil eds., 2006).
} 
Whereas in democracy, institutions incentivize the willing transfer of power after an electoral loss, authoritarians face graver risks from government failure. These include not just loss of power, but imprisonment, loss of assets, exile, or even death. Greater risk means that, while authoritarians desire the public or club goods that can be obtained through international cooperation, they also are mindful of unanticipated costs that might arise. They are risk-averse with regard to the future, with high discount rates for benefits, and a low discount rate for costs.

Another distinction has to do with the character of desirable cooperation. The threat of internal replacement by rivals means that, while authoritarians care a good deal about external security, internal security is a much graver concern. International cooperation that facilitates internal repression is desirable; that which risks empowering domestic political opponents is anathema.

Finally, the two types of regimes differ in their demand for transparency. Information is not freely available to ordinary citizens in an autocracy. Democracies have their secrets too, and democratic governments often seek to fool the public. But they have nothing like the closed decision-making process that characterizes authoritarian regimes. ${ }^{48}$ An important feature of international law is its public visibility. International law involves public commitments, memorialized in treaties, statements, and public-facing behavior. The implication is that authoritarians may be concerned about overly constraining themselves in elaborate and transparent international institutions, which might create domestic backlash if anticipated benefits do not emerge. Such public evidence of a failed policy can hurt a democratic leader, but can end the authoritarian regime in its entirety. ${ }^{49}$ The theory thus expects less hands-tying by authoritarian governments, with less public making of commitments.

Transparency also has implications for third-party dispute resolution, a central feature of the international legal order since the establishment of the Permanent Court of International Justice in 1922. Third-party dispute resolution involves the public contestation of legal issues, and may carry risk of unanticipated costs for authoritarians which exceed those for democrats. Third-party dispute resolution can generate legal or policy losses that might cause embarrassment to a democratic regime; for a dictator, however, it could lead to mobilization with the potential to topple a government. In general, we should not expect authoritarians to submit to the authority of dispute resolution bodies, at least without a specific assessment of the associated risks attendant in a particular dispute. Broad ex ante delegations to courts are less desirable than case-specific submissions in which the parties can assess the particular costs and benefits after the conflict has arisen.

The analysis so far has not taken power into account. Clearly power is a major determinant of states' behavior in international law. The United States at the end of the Cold War, and particularly after the Clinton administration, deployed what Detlev Vagts called "hegemonic international law," by which it sought to pick and choose which obligations it followed..$^{50}$ Vagts noted that "( $\mathrm{t}$ )reaties, since they represent constraints at some level on unilateral action by the parties, irritate hegemonists." 51 Such exceptionalism is not restricted to the United

\footnotetext{
${ }^{48}$ Christopher S.P. Magee \& John A Doces, Reconsidering Regime Type and Growth: Lies, Dictatorships, and Statistics, 59 InT'L STUD. Q. 223 (2015).

${ }^{49}$ Jessica L. Weeks, Autocratic Audience Costs: Regime Type and Signaling Resolve, 62 InT'L Org. 65 (2008).

50 Detlev Vagts, Hegemonic International Law, 95 AJIL 843 (2001).

${ }^{51} I d$. at 846.
} 
States: powerful states do not like constraint, and this is true of democratic as well as authoritarian states. ${ }^{52}$ If this is so, as relative power shifts toward authoritarian countries, we should expect treaties that are less constraining. But we ought to also recognize that some democracies, particularly the United States, are highly unrepresentative of the general category, simply by virtue of their power. The primary concern of this Article is to examine regime type, holding power constant.

To summarize: authoritarians will be interested in particular kinds of international public goods that benefit them and their supporters. We should expect, ceteris paribus, less willingness to include broad third-party dispute resolution clauses in treaties, and shallower legal commitments with more flexibility. We should also expect authoritarians to be less interested in public visibility, both in the sense of making fewer public binding commitments, and being less willing to tolerate institutions that increase domestic transparency. Authoritarian use of general international law, then, is different in theory from that of democracies, and more consistent with traditional notions of sovereignty that emphasize noninterference in internal affairs. As the number of authoritarian regimes increases, we should expect international law to increasingly take on the character of that demanded by authoritarians.

There is a further possibility, however, which is that authoritarian use of international law will support normative development that specifically enhances authoritarianism. ${ }^{53}$ This is what I mean by authoritarian international law. Such norms might facilitate cooperation across borders to repress regime opponents, enhancing the security of authoritarian rule. They might discourage freedoms of expression and association. They might also facilitate the dilution of democratic institutions and norms through practices and rhetoric that undermine them, turning general international law more authoritarian.

This is a project that might bring together diverse authoritarian regimes, which otherwise have few ideological commonalities. There is scant evidence that authoritarians are generally cooperative with each other, and war among authoritarian regimes is frequent, in contrast with war among democracies. ${ }^{54}$ Yet, as documented below, we have recently seen coordination on international law by regimes as diverse as Iran, Russia, and China. Such regimes have a common interest in reasserting norms of noninterference but also in developing new concepts to facilitate cross-border repression.

A large literature asks about the role of international organizations in facilitating democracy. ${ }^{55}$ Setting aside the question of whether international cooperation is inherently undemocratic in that it removes questions from the national political conversation, ${ }^{56}$ international

${ }^{52}$ Anu Bradford \& Eric A. Posner, Universal Exceptionalism in International Law?, 52 HARV. InT'L L.J. 3 (2011).

53 Cf. Congyan Cai, The Rise of China and International Law: Taking Chinese Exceptionalism Seriously 9 (2019) (states are both law users and law makers).

54 Bruce Russett \& John R. Oneal, Triangulating Peace: Democracy, Interdependence, and INTERNATIONAL ORGANIZATIONS (2000).

55 Jon C. Pevehouse, Democracy from Above: Regional Organizations and Democratization (2005); Jon C. Pevehouse, Democracy from the Outside-In? International Organizations and Democratization, 56 InT'L Org 515 (2002); Edward D. Mansfield \& Jon C. Pevehouse, Democratization and International Organizations, 60 InT'L ORg. 137 (2006); Emilie Hafner-Burton, Trading Human Rights: How Preferential Trade Agreements Influence Government Repression, 59 InT'L ORG 593 (2005); Paul Poast \& Johannes Urpelainen, How International Organizations Support Democratization: Preventing Authoritarian Reversals or Promoting Consolidation?, 67 WORLD POL. 72 (2015).

${ }^{56}$ See Martin Flaherty, Judicial Globalization in Service of Self-Government, 20 Eтн. \& InT’L AFF. 477 (2006); John Glenn, Global Governance and the Democratic Deficit: Stifling the Voice of the South, 29 THIRD WORLD Q. 217 
organizations have been very actively engaged in the direct promotion and defense of democracy, through international norms, monitoring, and enforcement. ${ }^{57}$ In theory, authoritarian regimes are capable of the same kind of activity, in which democratic institutions are undermined and authoritarian regimes stabilized through international cooperation. ${ }^{58} \mathrm{~A}$ recent literature on "autocracy promotion" documents how this is done using a variety of means. 59 The consensus seems to be that today's autocracies, unlike democracies, are not inherently driven to extend autocratic form, but act defensively to resist democracy promotion and to shore up particular allies. ${ }^{60}$ But in an increasingly interdependent world, such defensive action requires more active cooperation, which law can facilitate.

Table 1 summarizes the features of authoritarian international law, comparing and contrasting it with pro-democratic international law (into which are incorporated many of the features of liberal international law), and general international law. These are ideal types, not pure and exclusive categories, but the table is nevertheless a useful heuristic to guide the reader. The central prediction of the Article is that as the number of authoritarian regimes in the international system increases, we should observe a rightward drift in Table 1, toward active use of international cooperation to strengthen authoritarian rule, and ultimately to trying to shape the very content of international law. These shifts may not be sharp, but could result from a set of small qualitative changes that add up to a qualitative transformation, with more discourse, practices, and rules that have the characteristics described.

\section{Behavior of Democratic and Authoritarian Governments in the Postwar Period}

In this Part, I present some basic descriptive data on core international legal behavior during the postwar period, including the formation of international law, participation in multilateral treaty regimes, the conclusion of bilateral treaties, and the willingness to bring disputes before international courts and tribunals. The evidence helps us to understand whether and how democracies and authoritarians act differently, in keeping with the theory laid out in Part II, as a way of framing the developments described in Part IV. While the large literature on the

(2008); but see Theresa Squatrito, Conditions of Democracy-Enhancing Multilateralism: Expansion of Rights Protections in Europe?, 38 Rev. InT'L STUd. 707 (2012); Robert Keohane, Stephen Macedo \& Andrew Moravcsik, Democracy-Enhancing Multilateralism, 63 INT'L ORG. 1 (2009); see generally Global GOVERNANCE and Democracy: A Multidisciplinary Analysis (Jan Wouters, Antoon Braeckman, Matthias Lievens \& Emilie Bécault eds., 2015).

57 See Jorge Heine \& Brigitte Weifen, 21st Century Democracy Promotion in the Americas: Standing Up for the Polity (2014); The International Dimensions of Democratization: Europe and the Americas (Lawrence Whitehead ed., 1996). For examples of democracy-promoting instruments, see Lomé Declaration for an OAU Response to Unconstitutional Changes of Government, AHG/Decl.5 (XXXVI); African Charter on Democracy, Elections and Governance; Decision on the Prevention of Unconstitutional Changes of Government and Strengthening the Capacity of the African Union (Assembly/A/Dec. 269 XIV); InterAmerican Democratic Charter (2001).

58 See Eugénia C. Heldt \& Henning Schmidtke, Global Democracy in Decline? How Rising Authoritarianism Limits Democratic Control Over International Institutions, 25 Global Governance: A ReVIEW OF Multilateralism and International Organizations 231 (2019).

${ }^{59}$ Katsiaryna Yakouchyk, Beyond Autocracy Promotion: A Review, 17 Pol. STud. Rev. 147 (2018); Thomas Carothers, The Backlash Against Democracy Promotion, 85 For. Aff. 55 (2006); Lawrence Whitehead, AntiDemocracy Promotion: Four Strategies in Search of a Framework, 10 TaIWAN J. Dem. 1 (2014).

60 See generally Anastassia V. Obydenkova \& Alexander Libman, Authoritarian Regionalism in the World of International Organizations: Global Perspective and the Eurasian Enigma (2019). 
TABLE 1.

Summary of Features of International LaW Categories

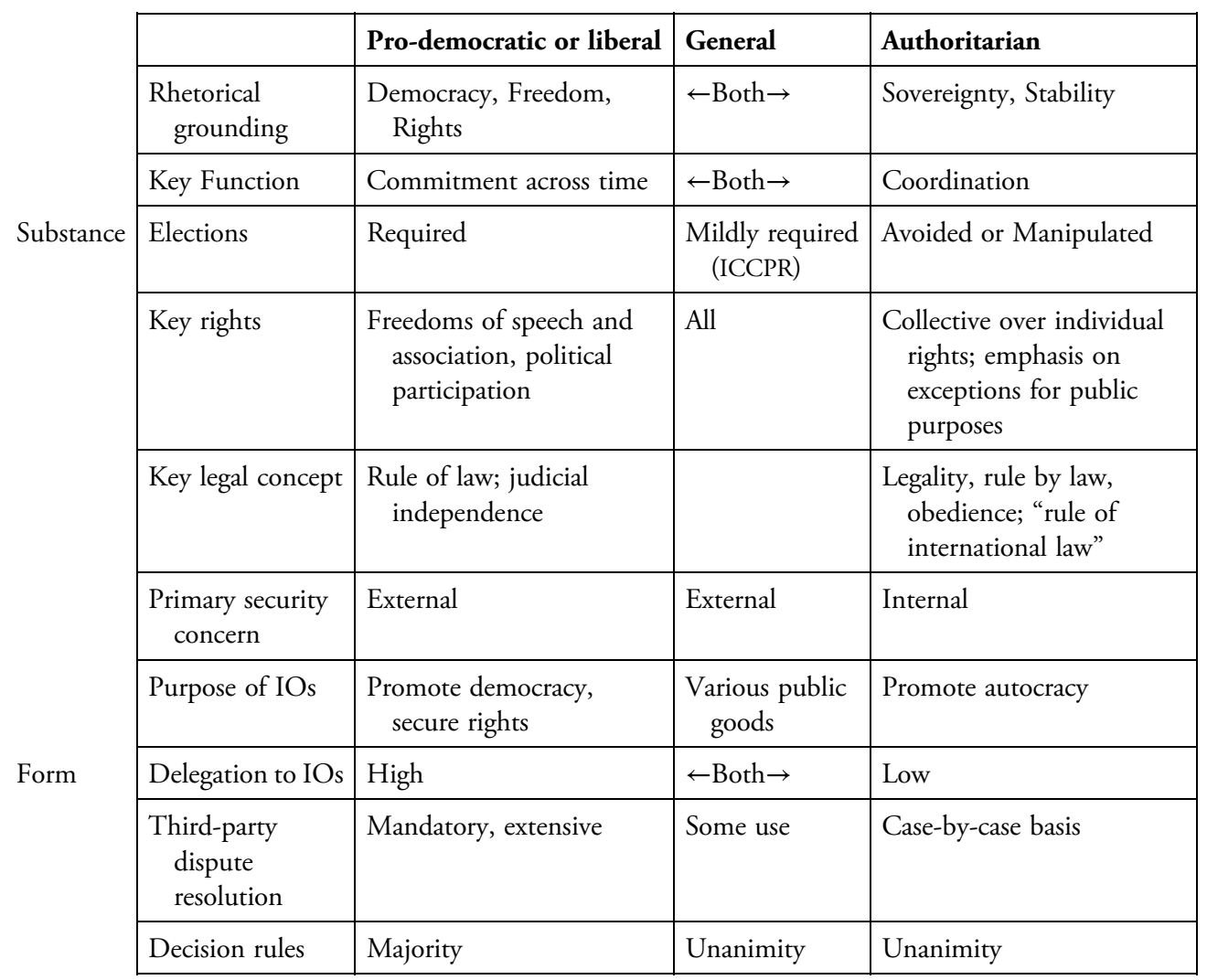

democratic peace has shown that democracies are unlikely to fight each other, the focus here is on international legal activity, which has been less systematically studied. ${ }^{61}$

While the Article relies on a relatively thin definition of democracy as its core variable of inquiry, there is no standard empirical measure that precisely captures this definition. Indeed, the measurement of democracy is itself the object of an entire field of inquiry in political science, with a great deal of disagreement about the relationship of concepts and measures. ${ }^{62}$ In the data that follow, unless otherwise stated, I use a standard measure for democracy: the Polity IV database, which rates countries from 10 (full democracy) to -10 (full autocracy) on a 21 -point scale. This measure has the advantage of extended time coverage, going back to 1800 , and is updated each year. A conventional way of transforming these data into a binary measure of democracy is to code any country-year in with a score of 6 or

${ }^{61}$ Bruce Russett, Christopher Layne, David E. Spiro \& Michael W. Doyle, The Democratic Peace, 19 InT'L SEC. 164 (1995); John R. Oneal \& Bruce M. Russett. The Classical Liberals Were Right: Democracy, Interdependence, and Conflict, 1950-1985, 41 INT'L STUD. Q. 267 (1997); Randolph M. Siverson \& Juliann Emmons, Birds of a Feather: Democratic Political Systems and Alliance Choices in the Twentieth Century, 35 J. Conf. Res. 285 (1991).

${ }^{62}$ John Gerring, et al., Conceptualizing and Measuring Democracy: A New Approach, 9 PersP. POL. 247 (2011); Dryzek, supra note 19. 
above in the Polity 2 measure as the cutoff for democracy. ${ }^{63}$ Using this measure, roughly 40 percent of all country-years have been democratic since 1946. If the use of international law was evenly spread across regimes, we should see democracies engaged in about 40 percent of the activity, rising above 50 percent only after 1990 with the so-called "Third Wave" of Democracy. ${ }^{64}$

This is not what we observe. Instead, we see that democracies are overwhelmingly more likely to engage in publicly reported treaty-making. Consider first a dataset drawn from the United Nations Treaty Series (UNTS), a monthly listing that reports all treaties deposited with the United Nations. The data were initially gathered in the World Treaty Index, and supplemented with additional hand-coded data from the UNTS beginning in the year 2000 , to create a dataset of more than 9,000 bilateral treaties (and several thousand multilateral treaties). I then examined the joint qualities of pairs of countries concluding bilateral treaties. As Table 2 indicates, the vast majority of these treaties were concluded by democratic dyads, even though such dyads were not a majority of possible pairs until after $1990 .{ }^{65}$ Any given authoritarian regime is more than ten times as likely to conclude a treaty with a democracy than with a fellow authoritarian. ${ }^{66}$

To be sure, these data are subject to selection effects. It is possible, even probable, that countries vary in their practice of depositing treaties with the United Nations and making them public. While international lawyers have sometimes encouraged the practice of deposit and publication, and even sought to condition legal force on the practice, the acceptance of treaties as binding ultimately depends on the decentralized behavior of individual states, which vary in both capacity and inclination. ${ }^{67}$ While liberal democracies are also known to keep agreements secret, both theory and casual observation suggest that nondemocracies are less likely to submit treaties to public depositaries. The People's Republic of China, for example, submitted no treaties to the UNTS until 1985, fourteen years after it joined the United Nations. ${ }^{68}$

Another way to examine differential approaches to treaty-making behavior is to ask which kinds of countries have signed the most treaties. Figure 1 below divides countries into quintiles using the Varieties of Democracy "Liberal Democracy" index, and asks which types of

${ }^{63}$ Another alternative cutoff is 7 or above. In the full dataset through $2017,3.2 \%$ of country-years have score 6 , and $3.2 \%$ have score 7 , giving a sense of the range of variation introduced by the decision to use the cutoff of 6 . For country-years after 1945 , the percentages are $4.6 \%$ for score 6 and $4.2 \%$ for score 7 .

${ }^{64}$ Samuel Huntington, The Third Wave: Democratization in the Late Twentieth Century (1991).

65 The UNTS also includes some 5,650 treaties between countries and international organizations. Sixty percent of these $(n=3360)$ are with democracies.

${ }^{66}$ Unreported t-tests confirm these differences are significant at a $99 \%$ confidence level.

${ }^{67}$ Megan Donaldson, The Survival of the Secret Treaty: Publicity, Secrecy, and Legality in the International Order, 111 AJIL 575 (2017). She cites an estimate that the overall registration of treaties is roughly about $50 \%$. The idea that deposit would be necessary for bindingness was initially advanced through Article 18 of the Covenant of the League of Nations ("Every treaty or international engagement entered into hereafter by any Member of the League shall be forthwith registered with the Secretariat and shall as soon as possible be published by it. No such treaty or international engagement shall be binding until so registered."). Its successor was Article 102 in the United Nations Charter.

${ }^{68}$ Donaldson, supra note 67, at n. 278. Other data on file suggests that the differential treaty practices are less pronounced when it comes to international economic law. For investment, trade and labor agreements, authoritarians are significantly less likely to conclude treaties than are democracies, but more likely than what is reported above. For data, see Online Appendix, available at http://comparativeconstitutionsproject.org/files/ AJIL_Online_Appendix.zip. 
TABLE 2.

Bilateral Treaties, 1949-2017

\begin{tabular}{lcc}
\hline Dyad Type & \% of Treaties & $\begin{array}{c}\text { Probability of concluding } \\
\text { a treaty in any given year }\end{array}$ \\
\hline Both parties democratic & $64 \%(\mathrm{~N}=5,761)$ & $0.370 \%$ \\
Half-democratic & $34 \%(\mathrm{~N}=3,083)$ & $0.205 \%$ \\
Authoritarian & $2 \%(\mathrm{~N}=168)$ & $0.015 \%$ \\
\hline
\end{tabular}

Source: Ward \& Gleditsch; Center for Systemic Peace, supplemented by author. N = 9,012.

countries are parties to the most treaties. The highest-level democracies join more treaties by an order of magnitude. In statistical analysis available in an online appendix, I confirm this in a multivariate model, controlling for wealth, population, and the number of contiguous countries (since more neighbors implies more possibility of joint public goods production). ${ }^{69}$

A host of other evidence shows that democracies and authoritarians behave differently on the international plane. Table 3 shows the set of contentious cases filed at the International Court of Justice (ICJ) since its establishment in 1947. While the number of such cases has risen and fallen across decades, democracies are generally overrepresented in filing cases. ${ }^{70}$

Other adjudicative settings have an even more pronounced dominance by democratic countries. For example, the International Tribunal for the Law of the Sea (ITLOS) was set up in 1994 under the United Nations Convention on the Law of the Sea (UNCLOS). The Tribunal operates in roughly the same way as the ICJ, in that there is both an advisory and a contentious jurisdiction, and the latter generally requires consent (with some exceptions). As of 2018, there have been twenty-five contentious cases. Only three of these-the 2002 case of The Volga brought by Russia against Australia, the 2003 case concerning Land Reclamation by Singapore in and Around the Straits of Johor brought by Malaysia against Singapore, and the 2009 case on Maritime Delimitation in the Bay of Bengal, brought by Bangladesh and accepted by Myanmar-involved claimants that were not democracies. ${ }^{71}$ In six other cases, each involving a seizure of a fishing ship, the respondent state was a nondemocracy. ${ }^{72}$ These cases involved demands for prompt release, brought under UNCLOS Article 292(1), pursuant to which the Tribunal has residual jurisdiction, and thus respondents had little choice but to participate. ${ }^{73}$ Therefore, around 90 percent of cases were brought by democracies.

69 For data, see Online Appendix, available at http://comparativeconstitutionsproject.org/files/ AJIL_Online_Appendix.zip.

${ }^{70}$ Note the data excludes requests for revision or interpretation of a judgment but includes situations in which multiple suits are filed against different countries under the same set of facts. The data also excludes countries not rated in the Polity data, such as microstates like the Marshall Islands-even though that country has been continuously democratic since its independence in 1979 and has sued before the ICJ.

${ }^{71}$ Russia was rated a six on the Polity scale that year, just at the conventional cutoff of democracy, but we include it in the discussion above in light of its subsequent slippage.

${ }^{72}$ These were the two M/V Saiga cases brought in 1997 by St. Vincent and the Grenadines against Guinea, the Chaisiri Reefer 2 case brought by Panama against Yemen in 2001, the two cases involving the Hoshinmaru and Tomimaru brought in 2007 by Japan against Russia, and the Arctic Sunrise case brought in 2013 by the Netherlands against Russia.

${ }^{73}$ UNCLOS Annex VII allows cases to be brought to arbitration at the Permanent Court of Arbitration in The Hague. As of this writing, the Permanent Court of Arbitration (PCA) has served as registry for thirteen cases, all but one of which (Malaysia-Singapore, initiated in 2003 and settled in 2005) were initiated by democracies. 


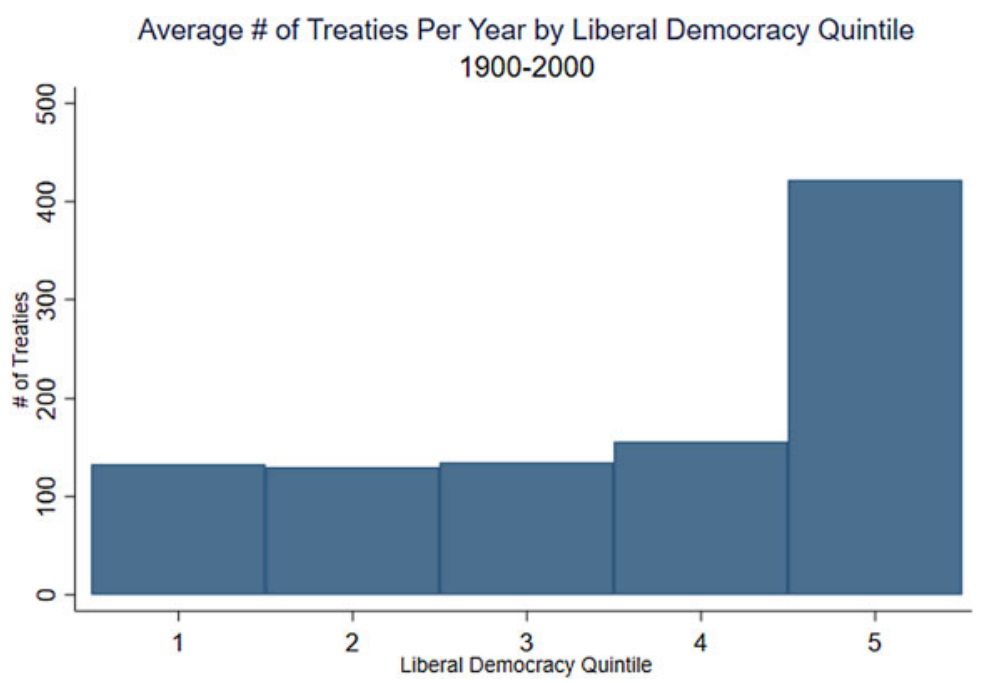

Figure 1. Treaties by Democracy Quintile

Source: Word Treaty Index and Center for Systemic Peace.

Consider also the Investor-State Dispute Settlement (ISDS) system, which has come under increasing scrutiny in recent decades, as the number and variety of claims pursued under it has expanded. Table 4 shows the reported ISDS cases filed through 2015. We see that the majority of cases are between democratic dyads, even though those dyads are only around a quarter of the entire set of bilateral investment treaties (BITs). Claimants from democratic countries are far more likely to file a case-a particularly interesting finding because some claimants can choose their nationality strategically. ${ }^{74}$ While the possibility that firms in authoritarian countries might use a subsidiary located in a democracy to bring the claim could suggest some bias in the data, any bias can also be considered evidence of the underlying point that there is some advantage to democratic home state status for investors.

Finally, consider the role of democracies in international organizations, which have expanded significantly in the postwar period. Figure 2 below presents selected data from the Correlates of War project on Intergovernmental Organizations (IGOs). ${ }^{75}$ One way of getting at the relative propensities of democracies to join IGOs is to ask about whether the average member of an organization is a democracy. The solid line in Figure 2 shows that the number of IGOs whose average member is democratic (as measured by Polity score) has risen over time. The number of IGOs whose average member is a "hybrid" or soft authoritarian regime, represented by the dotted line, has also been increasing over time. Such IGOs now are roughly as common as those whose average member is a democracy.

I also measure, for each international organization in the data, the average percentage of democracies among the member states, in the year of IGO formation. Interestingly, the most

\footnotetext{
${ }^{74}$ See, e.g., Philip Morris Asia Ltd v. Commonwealth of Australia, UNCITRAL, PCA Case No. 2012-12; Tokios Tokelès v. Ukraine, Decision on Jurisdiction and Dissent, ICSID Case No ARB/02/18, 20 ICSID Rev-FILJ 205, IIC 258 (2004)

${ }^{75}$ Jon Pevehouse, Timothy Nordstrom \& Kevin Warnke, Intergovernmental Organizations, 1815-2000: A New Correlates of War Data Set, Version 3.0 2.1, available at http://www.correlatesofwar.org/data-sets/IGOs.
} 
TABLE 3.

Contentious Cases at the International Court of Justice

\begin{tabular}{|c|c|c|c|c|c|c|c|c|}
\hline Category & $1947-59$ & $1960-69$ & $1970-79$ & $1980-89$ & $1990-99$ & $2000-09$ & 2010-17 & TOTAL \\
\hline $\begin{array}{l}\text { Total cases filed by } \\
\text { democracies (incl. } \\
\text { Special Agreements) }\end{array}$ & 26 & 3 & 7 & 5 & 10 & 19 & 12 & 82 \\
\hline Total cases & 32 & 6 & 9 & 12 & 33 & 23 & 16 & 131 \\
\hline $\begin{array}{l}\% \text { all cases filed } \\
\text { by democracies }\end{array}$ & 81 & 50 & 86 & 42 & 30 & 83 & 75 & 63 \\
\hline $\begin{array}{c}\% \text { of democratic } \\
\text { country-years }\end{array}$ & 31 & 29 & 26 & 30 & 46 & 54 & 57 & 40 \\
\hline
\end{tabular}

Source: Author's coding from website of International Court of Justice.

TABLE 4.

Reported ISDS Cases Through 2015

\begin{tabular}{llccc}
\hline $\begin{array}{l}\text { Claimant home } \\
\text { country }\end{array}$ & $\begin{array}{l}\text { Respondent } \\
\text { country }\end{array}$ & $\begin{array}{c}\text { Number of } \\
\text { cases }\end{array}$ & $\begin{array}{c}\text { Number of BIT } \\
\text { dyad years }\end{array}$ & $\begin{array}{c}\text { Probability of claim in } \\
\text { dyad-year }\end{array}$ \\
\hline Democracy & Democracy & 457 & 1412 & 0.32 \\
Democracy & Autocracy & 169 & 1066 & 0.16 \\
Autocracy & Democracy & 24 & 1066 & 0.02 \\
Autocracy & Autocracy & 26 & 594 & 0.04 \\
Data not available & & 125 & 964 & 0.13 \\
TOTAL & & 801 & 5102 & 0.16 \\
\hline
\end{tabular}

Source: Data from Weijia Rao, Domestic Politics and Settlement in Investment Treaty Arbitration (manuscript). Denominator for dyad-year is every BIT dyad since 1959, even though first ISDS claim was not filed until the 1970s.

common percentage of democracies in an IGO is either one hundred or zero. Most international organizations in other words, are composed of countries that have a similar regime type.

Part II put forward the conjecture that the structure of authoritarian-dominated international organizations would be less likely to promote transparency and third-party dispute resolution. To evaluate this claim, I examine a subset of international organizations designated as general-purpose by Cottiero and Haggard. ${ }^{76}$ I use their independently selected set of cases and then develop original data on the internal features of on ninety-four different international organizations, using their founding charters and subsequent documents. I review whether these documents refer to terms such as security, democracy, the rule of law, and human rights, and examine several features of their legal-institutional form: whether they establish a court or legal committee of some kind, whether they grant immunity to their staff (as a possible measure of institutionalization), and the number of words in the founding charter, as an indicator of specificity and complexity of the organization. Table 5 presents the statistics on the percentage of international organizations with each feature, categorized by

\footnotetext{
${ }^{76}$ Cristina Cottiero \& Stephen Haggard, Stabilizing Authoritarian Rule: The Role of International Institutions (paper presented at annual meeting of the American Political Science Association, 2019).
} 


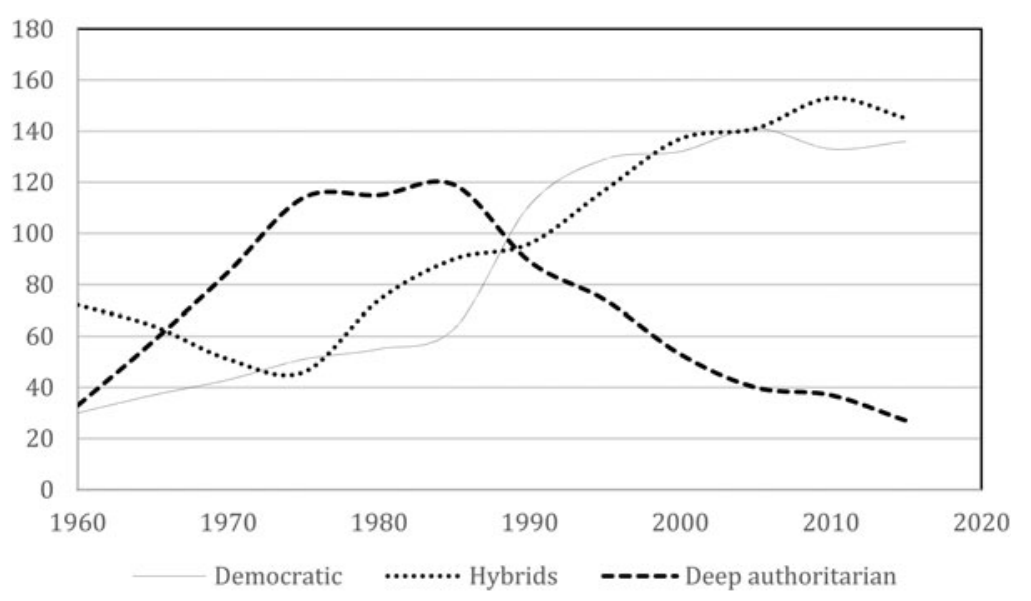

Figure 2. Number of International Organizations Over Time by Average Polity Score

Source: Jon Pevehouse, et al., Tracking Organizations in the World: The Correlates of War IGO Version 3.o Datasets, J. PEACE RES. (forthcoming), available at https://correlatesofwar.org/data-sets/IGOs.

whether they are democratic or not (the first two columns) and then by depth of authoritarianism among members, all as defined by the average Polity score of their members in the year of founding. (The left-most column thus loosely corresponds to the right side of Figure 3, while the right-most column loosely corresponds to the left side of Figure 3.)

These features of the charters establishing international organizations suggest potential differences in the ways that authoritarians and democrats cooperate. For many features of IGO charter language, we observe no general difference between the two regime types in the first two columns. Authoritarian international organization charters mention human rights and democracy at the same rate as democratic ones, and are actually more likely to contain provisions on dispute resolution and immunity for staff. But international organizations composed mostly of democracies have more detailed founding charters, implying more "precision" of obligation. ${ }^{77}$ Furthermore, the right-most column suggests that international organizations composed primarily of deeply authoritarian regimes - the ones that may be most incentivized to use what I call authoritarian international law-are indeed less likely to use the fig-leaf of talk about human rights and democracy, and are less likely to establish third-party dispute resolution mechanisms in the form of a court.

In related work, I have provided many more examples of how authoritarian and democratic countries differ in their use of international law, with the latter being more likely to deploy international law and use its institutions. ${ }^{78}$ These findings are consistent with the work of many other scholars. In trade, for example, Reinhardt found that democracies are more disputatious overall; they are both more likely to initiate disputes before the World Trade Organization (WTO) and the General Agreement on Tariffs and Trade (GATT), as well

\footnotetext{
${ }^{77}$ Kenneth W. Abbott, Robert O. Keohane, Andrew Moravcsik, Anne-Marie Slaughter \& Duncan Snidal, The Concept of Legalization, 54 INT'L ORG. 401 (2000).

78 Democracies and International Law (draft on file with author).
} 
TABLE 5.

Internal Features of International Organizations

\begin{tabular}{|c|c|c|c|c|}
\hline & Democratic & All Autocratic & Hybrids Only & Deep Authoritarians Only \\
\hline & Avg. Polity $>5(n=34)$ & Avg. Polity < $5.01(n=44)$ & Avg. Polity $0-5(n=21)$ & Avg. Polity $<0(\mathrm{n}=23)$ \\
\hline Mention democracy & 0.41 & 0.43 & 0.62 & $0.23^{* *}$ \\
\hline Mention rule of law & 0.38 & 0.29 & 0.48 & $0.1^{* * *}$ \\
\hline Mention human rights & 0.41 & 0.50 & 0.76 & $.24^{* * *}$ \\
\hline Mention international law & 0.44 & 0.44 & 0.57 & 0.33 \\
\hline Norm v. unconstitutional changes in government & 0.03 & 0.02 & 0.05 & 0 \\
\hline Mention security & 0.62 & 0.71 & 0.81 & 0.62 \\
\hline Dispute resolution system & $0.50^{*}$ & 0.67 & 0.67 & 0.67 \\
\hline Establish Court & 0.3 & 0.33 & 0.48 & $.19^{*}$ \\
\hline \# Words & $16428^{*}$ & 7295 & 8428 & 6269 \\
\hline Immunity for staff & $0.51^{* *}$ & 0.71 & 0.71 & 0.58 \\
\hline Create legal committee & 0.24 & 0.15 & 0.29 & $.09^{* *}$ \\
\hline
\end{tabular}

$\mathrm{N}=94$. Key: ${ }^{*}$ indicates $\mathrm{t}$-test for difference in means between that category and all others is significant at the .10 level; ${ }^{* *} \mathrm{t}$-test significant at $5 \%$ level; ${ }^{* * *} \mathrm{t}$-test significant at .01 level. 


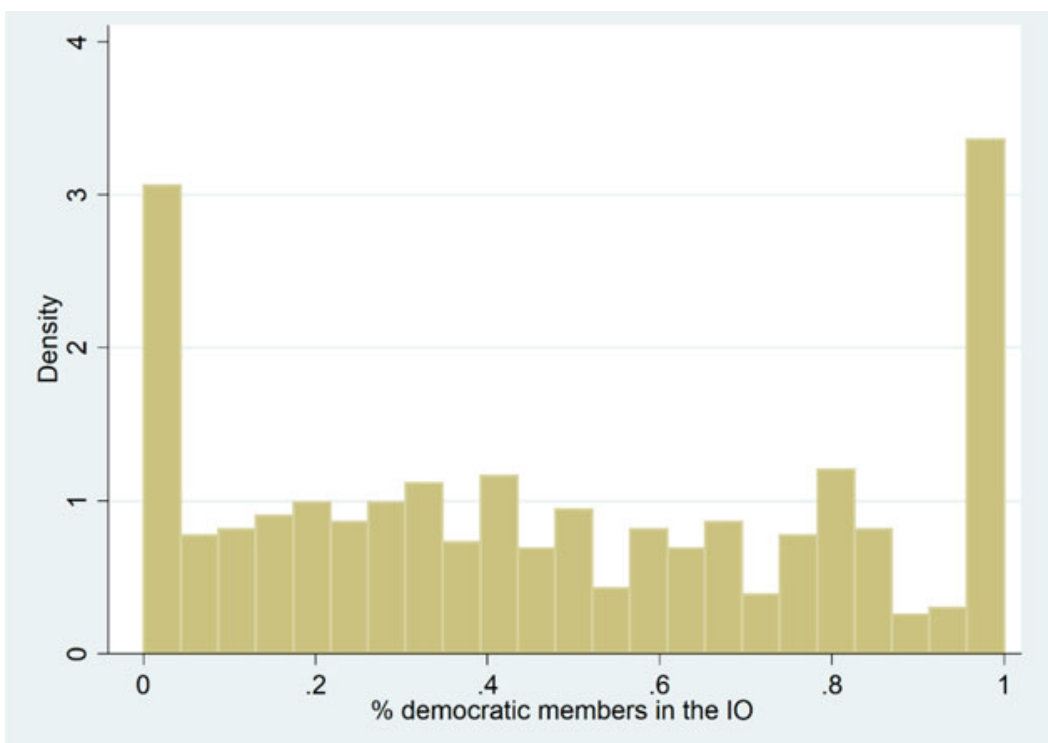

FIgure 3. The Bimodal Distribution of International Organizations

Source: Jon Pevehouse, Timothy Nordstrom \& Kevin Warnke Intergovernmental Organizations, 1815-2000: A New Correlates of War Data Set.

as to be targeted by other parties (regardless of the complainant's regime type). ${ }^{79}$ Similarly, Sattler and Bernauer conducted a statistical analysis which found that "domestic politics appears to be very important for dispute initiation and is, arguably, more important than economic power and trade dependence. More democratic countries are much more likely to become involved in trade disputes. Democratic countries both initiate significantly more trade disputes and also become the target of a dispute significantly more often." 80 Pelc, studying investment law using his own data, found that ISDS cases disproportionately target democracies rather than autocratic regimes with weak rule of law. ${ }^{81} \mathrm{He}$ found that 64 percent of disputes in the last two decades involved democracies, consistent with the data in Table 4. In terms of human rights, Bernard Boockman and Axel Dreher showed that democracies were more likely to support UN human rights resolutions than nondemocracies. ${ }^{82}$ Cosette Creamer and Beth Simmons demonstrated that democracies submit higher quality reports to human rights monitoring bodies (though may be no more likely to report in general). ${ }^{83}$

${ }^{79}$ Eric Reinhardt, Aggressive Multilateralism: The Determinants of GATT/WTO Dispute Initiation, 1948-1998, available at http://www.isr.umich.edu/cps/pewpa/archive/archive_99/19990004.pdf.

80 Thomas Sattler \& Thomas Bernauer, Dispute Initiation in the World Trade Organization, (manuscript), available at https://www.peio.me/wp-content/uploads/2014/04/Conf1_Bernauer.Sattler_Dispute.Initiation.WTO_. pdf.

${ }^{81}$ Krysztof J. Pelc, What Explains the Low Success Rate of Investor-State Disputes?, 71 INT'L OrG. 559 (2017).

82 Bernhard Boockman \& Alex Dreher, Do Human Rights Offenders Oppose Human Rights Resolutions in the United Nations?, 146 Pub. CHOICE 443, 462 (2011).

${ }^{83}$ Cosette D. Creamer \& Beth A. Simmons, Do Self-Reporting Regimes Matter? Evidence from the Convention Against Torture, 63 InT'L STUd. Q. 1051 (2019). 
The evidence presented in this Part shows that, consistent with the theory laid out in Part II, democracies are more likely to utilize international law to engage in cooperation and conflict resolution than are authoritarians. But the evidence on international organizations, in which authoritarian participation seems to be increasing, suggests that there is some change afoot and that authoritarians are cooperating in more sophisticated ways. I now turn to this phenomenon.

\section{The Evolution of Authoritarian International Law: From Use to Normative DEVELOPMENT}

This Part starts with an analogy from the study of national constitutional orders. As my colleagues and I at the Comparative Constitutions Project showed in a 2014 paper, there are many similarities between formal constitutions adopted in democracies and those in dictatorships. ${ }^{84}$ That work finds that most innovations in constitutional technology occur in democracies, but that authoritarians borrow these innovations in a lagged manner. When it comes to national constitutions, the scholarship indicates that that democracies innovate and authoritarians mimic and repurpose. ${ }^{85}$ The mechanism is that democracies confront governance problems and create new institutions such as rights to information, independent electoral commissions, and ombudsmen. As these institutions diffuse to other countries that are drafting constitutions, dictatorships mimic them. But with their laser-like focus on survival, dictators quickly learn to undermine the integrity of these institutions, and so the formal similarity masks differences in function. The purpose of the borrowing may be to enhance legitimacy by appearing democratic, but it also allows authoritarians to experiment with new institutions that can help extend their rule. Regardless of the goals, scholars have seen gradual convergence of form across regime type over time. The increasing use by authoritarians of institutions that originate in democracy-for example, elections, judges with some degree of autonomy, counter-corruption commissions, and long lists of rights-suggests that mimicry may be some benefit for authoritarian survival.

This borrowing and retooling can help facilitate "adaptive authoritarianism." This phrase originates in the study of Chinese politics, and is a characterization that seeks to explain the Chinese Communist Party's (CCP) surprising resilience and stability over the past few decades. ${ }^{86}$ While some scholars have argued that the CCP would inevitably democratize, ${ }^{87}$ studies of adaptive authoritarianism counter this view by offering a robust account of how the CCP's regime will remain resilient into the future. According to some scholars, the adoption

${ }^{84}$ Elkins, Ginsburg \& Melton, supra note 8.

${ }^{85} \mathrm{Id}$.

${ }^{86}$ Sebastian Heilmann, Red Swan: How Unorthodox Policymaking Facilitated China's Rise (2018); Elizabeth Perry \& Sebastian Heilmann, Embracing Uncertainty: Guerilla Policy Style and Adaptive Governance in China, in Mao's Invisible Hand: The Political Foundations of Adaptive Governance in China (Elizabeth J. Perry \& Sebastian Heilmann eds., 2014); Elizabeth Perry, Growing Pains: Challenges for a Rising China, Daedalus (2014); Andrew J. Nathan, China's Changing of the Guard: Authoritarian Resilience, 14 J. Deм. 6 (2003); Anna Ahlers \& Gunter Schubert, "Adaptive Authoritarianism" in Contemporary China: Identifying Zones of Legitimacy Building, in ReVIVING LegitimaCy (Deng Zhenglai \& Sujian Guo eds., 2011); David Shambaugh, China's Communist Party: Atrophy and Adaptation (2008); Titus Chen, China's Reaction to the Color Revolutions: Adaptive Authoritarianism in Full Swing, 34 AsIAN PERSP. 5 (2010).

${ }^{87}$ Susan L. Shirk, China: Fragile Superpower (2007); Gordon G. Chang, The Coming Collapse of China (2001). 
of new institutional innovations - including administrative law, freedom of information, and village elections-has allowed the regime to weather significant challenges. ${ }^{88} \mathrm{With}$ the increasingly authoritarian turn under Xi Jinping's leadership, these scholars seem to have the upper hand in the argument.

Might the use of international law follow a similar logic? Could authoritarians be retooling the machinery of international law to suit their own ends and help extend their rule? This Part provides evidence of gradual learning by authoritarian regimes and an evolution from formal mimicry to more sophisticated engagement with the machinery of international law. The focus is on regional organizations as important sites of cooperation and normative development. I begin with examples of authoritarian mimicry, including the Warsaw Pact, ASEAN, and the Eurasian Economic Community. I then turn to the Shanghai Cooperation Organization.

\section{Mimicry: The Warsaw Pact}

In 1955, a group of communist countries concluded a mutual defense treaty, six years after the formation of the North Atlantic Treaty Organization (NATO). ${ }^{89}$ A significant characteristic of the Warsaw Pact was that it was fundamentally reactive in nature. The treaty was conceived as a response to what the Soviet Union perceived as the encroaching influence of NATO; and, more specifically, to the inclusion of a remilitarized West Germany in the alliance. ${ }^{90}$ These political conditions were so central to the precipitation of the Pact's formation that they were written into the text of the treaty itself. The treaty's very first line affirms the importance of a collective security regime "irrespective of social and political systems," likely an implicit jab at NATO's rebuffs of the Soviet Union's attempts to join it in $1954 .{ }^{91}$ The same line goes on to explicitly reference as the treaty's motivation the "situation created in Europe by the ratification of the Paris agreements, which envisage the formation of a new military alignment in the shape of 'Western European Union,' with the participation of a remilitarized Western Germany and the integration of the latter in the North-Atlantic bloc."92

In the (relatively brief) text of the treaty itself, the Warsaw Pact established certain obligations that were incumbent on its members, mirroring those of the NATO treaty. These obligations included a commitment to settling intra-Pact disputes peacefully, and without the use of force (Article 1); a commitment to nuclear disarmament (Article 2); the establishment of a collective security regime under which all parties to the Pact will come to the assistance of any party under armed attack (Articles 3 and 4); the establishment of a Joint Command of the armed forces (Article 5); and the establishment of a Political Consultative Committee (Article

\footnotetext{
${ }^{88}$ Shambaugh, supra note 86.

${ }^{89}$ Treaty of Friendship, Cooperation and Mutual Assistance Between the People's Republic of Albania, the People's Republic of Bulgaria, the Hungarian People's Republic, the German Democratic Republic, the Polish People's Republic, the Rumanian People's Republic, the Union of Soviet Socialist Republics and the Czechoslovak Republic, May 14, 1955, available at http://avalon.law.yale.edu/20th_century/warsaw.asp.

${ }^{90}$ Eric Richardson, NATO, The Warsaw Pact, and the Iron Curtain (2017).

91 Treaty of Friendship, supra note 89, at pmbl., Art. 9 ("The present Treaty is open to the accession of other states, irrespective of their social and political systems. ...").

${ }^{92} I d$.
} 
6). The treaty closes with the stipulation that the Warsaw Pact would dissolve in the event that a pan-European system of collective defense is ever established.

In terms of the obligations and costs it imposed on its member states, the Warsaw Pact was modeled on the NATO treaty. ${ }^{93}$ Perhaps the most explicit and substantial obligation was the commitment to collective self-defense. In an interesting contrast with the Warsaw Pact treaty, the NATO treaty explicitly stipulates that "this Treaty shall be ratified and its provisions carried out by the Parties in accordance with their respective constitutional processes," 94 which for some of them would involve legislative approval. There was no such demand for legislative ratification in the Warsaw Pact treaty, which lacked what international organizations scholars call vertical enforcement - there were no domestic mechanisms designed to promote compliance. ${ }^{95}$ The barely hidden subtext was that the Pact did not really need domestic democratic approval to make it enforceable, as the shadow of Soviet power was the real force at work. In contrast, NATO members were invited to affirm the treaty obligations through national processes, which would presumably involve deeper commitment.

The life of the Warsaw Pact was in fact quite different from that of NATO. Whereas the latter involved a series of subsequent agreements and protocols, as well as disagreements among members, the Warsaw Pact was not a vital legal regime. ${ }^{96}$ Instead, it was a tool for Soviet domination of member states to ensure continued communist rule. Although the Pact promised "respect for the independence and sovereignty of states" and "noninterference in their internal affairs," 97 when the provisional revolutionary government of Hungary declared its intention to withdraw from the Warsaw Pact in 1956, Soviet troops invaded.

In addition, the Warsaw Treaty Organization was dissolved at the end of the Cold War, whereas NATO began to engage in collective military action in its aftermath. It expanded from twelve original members to twenty-nine current members. In the 1990s, NATO took military action in Bosnia and Kosovo; and in 2001, after the 9/11 attacks, it invoked the collective self-defense provisions of Article 5. In short, the legal obligations of NATO played some role in its life, whereas this was not the case for the Warsaw Pact. The Warsaw Pact was, largely, form without function, but it illustrates an international legal regime designed to maintain and extend authoritarian rule. ${ }^{98}$

\section{Sovereignty-Reinforcing Regionalism: ASEAN}

Another example of authoritarian use of international law, albeit more functional than the Warsaw Pact, is ASEAN). Founded in 1967 by five countries, ASEAN later expanded to six countries with the addition of Brunei in 1984, and eventually ten countries after the end of

93 RichaRdSON, supra note 90.

${ }^{94}$ NATO Treaty, Art. 11.

95 Harold Hongju Koh, How Is International Human Rights Law Enforced?, 74 InD. L.J. 1397, 1401 (1999).

96 See, e.g., Protocol to the North Atlantic Treaty on the Accession of the Federal Republic of Germany, Paris (1955); Agreement Between the Parties to the North Atlantic Treaty Regarding the Status of Their Forces, June 19, 1951; Protocol on the Status of International Military Headquarters Set Up Pursuant to the North Atlantic Treaty, Aug. 28, 1952; Agreement Among the States Parties to the North Atlantic Treaty and the Other States Participating in the Partnership for Peace Regarding the Status of Their Forces, June 19, 1995.

${ }_{97}$ Warsaw Pact, Art. 8 (1955).

98 A related organization that might be characterized as more functional was COMECON, created in 1949 , which played a role in rationalizing communist planning across countries in the Soviet bloc. It thus had a genuine function, albeit one that was sustained by brute force. See ObYdenKova \& Libman, supra note 60, at 116. 
the Cold War. It was an authoritarian international organization in the sense that none of its members were democracies; only the Philippines could be considered partly democratic at the time of its founding. Even today, only Indonesia can be considered a stable democracy, though Malaysia seems to be moving in that direction. But as originally conceived, ASEAN was designed to bolster relatively weak states and thus consolidate authoritarian rule.

ASEAN has gradually developed more significant programs of regional integration, most significantly in the 2007 adoption of the ASEAN Charter. ${ }^{99}$ It now encompasses an ASEAN Economic Community), a (very weak) human rights institution, and the ASEAN Regional Forum which is a security structure bringing together most of the countries with security interests in the Asian region. However, integration is not deep in either the economic or political spheres, especially when compared with regional organizations in Europe and Latin America. ${ }^{100}$ The region's economies are disparate in development levels and ambitions for legal integration are moving slowly. ASEAN is only weakly institutionalized in that its organs and process have little independent effect on outcomes of the region. ${ }^{101}$

Instead of promising "an ever-closer Union," the ASEAN Charter emphasizes the traditional principles of noninterference, sovereignty, and independence. ${ }^{102}$ This in turn drew on the Five Principles of Peaceful Coexistence, articulated by India and China in 1954 and reiterated at the Bandung Conference of 1955: (1) mutual respect for territorial integrity and sovereignty; (2) mutual nonaggression; (3) mutual noninterference in internal affairs; (4) equality and mutual benefit; and (5) peaceful coexistence. ${ }^{103}$ These principles-essentially Westphalian in character, but neither democratic nor authoritarian in essence-reflected the need for newly decolonized states to focus on the prerogatives of state-building.

Noninterference has guided ASEAN from its earliest days; above all, ASEAN's regionalism is sovereignty reinforcing. Sovereignty-reinforcing regionalism served the interests of statebuilding in a region where borders were largely determined by colonialism, and where each country is multiethnic. In places such as Mindanao, Pattani, Kachin State and Aceh, local demands for autonomy or even secession remain vital, and were even more stark in the early years of independence. Noninterference in ASEAN was not merely rhetorical, but meant that states had to refrain from openly supporting national liberation movements in their neighbors. In the early phases of state-building, the mutual commitment meant something real, and the lofty rhetoric of Bandung was deployed to help extend regime survival.

\footnotetext{
${ }^{99}$ See Association of Southeast Asian Nations [ASEAN] Charter (Nov. 20, 2007), available at https://asean.org/ asean/asean-charter/charter-of-the-association-of-southeast-asian-nations. The Charter was ratified by all ten members and came into force by October of 2008. ASEAN Press Release, ASEAN Embarks on New Era Charter Fully Ratified (Oct. 21, 2008), at https://asean.org/press-release-asean-embarks-on-new-era-asean-charter-fully-ratified-asean-secretariat.

100 See Pasha L. Hsieh \& Bryan Mercurio, ASEAN Law in the New Regional Economic Order: An Introductory Roadmap to the ASEAN Economic Community, in ASEAN LAW IN THE NEW Regional ECONOMIC Order: Global Trends and Shifting Paradigms 3, 10 (Pasha L. Hsieh \& Bryan Mercurio eds., 2019)

101 Tom Ginsburg, Eastphalia and East Asian Regionalism, 44 U.C. DAVIs L. REV. 859-77 (2011).

${ }^{102}$ ASEAN Charter, supra note 99, at ch. I, Art. 2.2(a), (e). Compare Treaty on European Union, pmbl. (Feb. 7, 1992) ("RESOLVED to continue the process of creating an ever closer union among the peoples of Europe.").

103 See generally Bandung, Global History and International Law: Critical Pasts and Pending Futures (Luis Eslava, Michael Fakhri \& Vashuki Nesiah eds., 2017); Zhou Gang, The Establishment of the Five Principles of Peaceful Coexistence and its Historical Contributions, Chinese People's Inst. of Foreign Affairs, 72 For. AfF. J. (2005).
} 
The “ASEAN Way" refers to a process of consultation and consensus, sometimes identified with many of the cultures in the region. It has meant that there was no regional criticism of the Khmer Rouge, the Burmese Junta, or Indonesia's occupation of East Timor. ASEAN's Westphalian style of regionalism is one in which political leaders gather to discuss mutual concerns but refrain from criticism and genuinely leave each other's "internal" affairs alone. This point is worth highlighting, particularly because of the claims of liberal international lawyers in the 1990s. There is plenty of "New World Order"-style cooperation among ASEAN bureaucrats, who have advanced a number of modest programs for educational and cultural cooperation, but there is neither deep integration nor much of a shift from classical Westphalian international law.

Increasingly, international legal cooperation within ASEAN has been utilized to defend authoritarianism in the member states. Cambodia's Hun Sen banned the main opposition party, the Cambodian National Rescue Party (CNRP), in 2017, en route to a complete victory in 2018 elections. When CNRP leaders sought to travel to Phnom Penh to engage in protests in November 2019, neighboring Thailand and Malaysia invoked the ASEAN principle of noninterference to bar their travel. ${ }^{104}$ Cambodia also sought (unsuccessfully) extradition from Malaysia on trumped-up charges against CNRP Vice-chair Mo Sochua. ${ }^{105}$ Thailand has extradited other Cambodian activists, including a woman whose crime was throwing a shoe at a ruling party billboard. ${ }^{106}$ At the same time, other extradition requests have been rejected, and a Model ASEAN Extradition Treaty retains a good deal of discretion for state parties who are requested to turn over fugitives, in keeping with the overall emphasis on state sovereignty of the regional organization. ${ }^{107}$

\section{Partial Institutionalization: The Eurasian Economic Union}

In 2014 Belarus, Russia, and Kazakhstan signed a treaty establishing the Eurasian Economic Union (EAEU), subsequently joined by Armenia and Kyrgyzstan. ${ }^{108}$ The EAEU emerged as the culmination of a process of gradual integration that grew out of the post-Soviet Commonwealth of Independent States (CIS), and absorbed a separate initiative called Central Asian Economic Cooperation. The EAEU's goals and institutional development have followed the pattern of the European Union, beginning with a Eurasian Economic Community (2000), a customs union (2007), and a single market (2012), before the full-fledged "Union" emerged. The EAEU structure mimics the European Union with a Supreme Council composed of the heads of state, an Intergovernmental Council composed of the prime ministers, a Court of Justice, and a Eurasian Economic Commission, which is an executive branch of bureaucrats, similar to the European Commission. The annual budget is

\footnotetext{
${ }^{104}$ Hannah Beech, With a Smile Southeast Asian Nations Protect an Authoritarian, N.Y. TIMES (Nov. 7. 2019), at https://www.nytimes.com/2019/11/07/world/asia/cambodia-hun-sen-mu-sochua.html?searchResultPosition=1.

${ }^{105} \mathrm{Id}$.

${ }^{106}$ Yiamyut Sutthichaya \& Thaweeporn Kummetha, Bangkok-Phnom Penh Deal? Deportation of Sam Sokha and Uncertain Future of Thai Exiles, Prachathai English (Feb 23, 2018), at https://prachatai.com/english/node/ 7645 .

1072019 ASEAN Model Extradition Treaty, adopted Oct. 12, 2018, available at https://cil.nus.edu.sg/databasecil/2019-model-asean-extradition-treaty.

108 The Treaty on the Eurasian Economic Union, opened for signature May 29, 2014. Along with Tajikistan, these are the nations that are member states in the Russian sponsored Eurasian Development Bank.
} 
roughly $\$ 10$ million, and it has approximately 1,200 employees whose positions are allocated in accordance with the overall population share of the member states. It does not yet, however, have a parliamentary body or common currency, although both have been broached.

The EAEU has also adopted the language of "enlargement," and has concluded several free trade agreements, including with neighboring Ukraine, Moldova, Uzbekistan, and Tajikistan in the CIS Free Trade Agreement. ${ }^{109}$ The only two additional countries to join as full members, interestingly, were hybrid regimes, Armenia and the Kyrgyz Republic. These countries were invited to membership in reaction to the "Eastern Partnership" of the EU European Neighborhood Policy, which had targeted these nations. ${ }^{110}$ In this sense, the deployment of international cooperation was motivated by a defensive strategy to prevent neighboring states from moving too much into the Western democratic sphere.

Unlike many other international organizations created by authoritarian governments, but like the European Union, disputes are resolved by a judicial body. The current iteration, the Court of the Eurasian Economic Union, followed the CIS Free Trade Area Court, the economic court of the CIS and a Court of the Eurasian Economic Community. Following the establishment of the Eurasian Economic Union, the new Court was set up in 2015, without legal continuity carrying over from prior courts. ${ }^{111}$ None of these courts have been particularly busy; there were only thirteen interstate disputes in its first twenty years of operation of the CIS Court, but the tribunal was called upon regularly (more than one hundred times) to interpret CIS acts and agreements. ${ }^{112}$ Many of these cases are brought by the organs and civil servants of the organization. This suggests a body with some functional role beyond a mere talk shop for heads of state. The EAEU, from this point of view, reflects the greater sophistication of institutional form, even if it involves mimicry of the democratic innovations of the European Union. At the same time, the Court's ambit is limited and there is no chance of it becoming a major engine of legal development like the Court of Justice of the European Union. ${ }^{113}$ The Statute of the Court is explicit that: "No decision of the Court may alter and/or override the effective rules of the Union law and the legislation of the Member States, nor may it create new ones." ${ }^{114}$ Instead, an EAEU court finding that the Commission's decision is not in line with the Treaty or international treaties within the Union has no legal effect unless accepted by the Commission or Council. ${ }^{115}$ This is an executive-centered international organization, which it is impossible to imagine evolving into a constitutional federalism of the European type, in which international organs can constrain the member states themselves. However, the overall

109 Seljan Verdiyeva, The Eurasian Economic Union: Problems and Prospects, 19 J. World InV. \& Trade 722 (2018).

${ }^{110}$ Alexander Libman \& Anastassia V. Obydenkova, Regional International Organizations as a Strategy of Autocracy: The Eurasian Economic Union and Russian Foreign Policy, 94 INT'L AfF. 1037 (2018); see generally OBYDENKOVA \& LiBMAN, supra note 60.

${ }^{111}$ Ekaterina Diyachenko \& Kirill Entin, The Court of the Eurasian Economic Union: Challenges and Perspectives,

5 Russian L.J. 53 (2017), at https://www.russianlawjournal.org/jour/article/view/273?locale=en_US.

112 Id.

${ }^{113}$ Alessandro Romano, Wrong Way to Direct Effect? Case Note on the Advisory Opinion of the Court of the Eurasian Economic Union Delivered on 4 April 2017 at the Request of the Republic of Belarus, 45 LEG. ISSUES ECON. INTEGRATION 211 (2018).

${ }^{114}$ Treaty on the Eurasian Economic Union, supra note 108, Annex 2, Art. 102.

${ }^{115}$ Id., Annex 2, Art. 111. 
organization has had some real, if limited, impact in expanding market access and in solidifying a customs union among its members.

\section{Toward Cooperation: The Shanghai Cooperation Organization}

Like the CIS and the Central Asian Cooperation initiative, the Shanghai Cooperation Organization (SCO) was originally formed as a response to the collapse of the Soviet Union, acting as a forum to demarcate borders between China and its new post-Soviet neighbors. Founding members were the so-called Shanghai Five-China, Russia, Kazakhstan, Kyrgyzstan, and Tajikistan-with Uzbekistan joining in 2001. In 2001, this cooperative forum was formalized and branded as the SCO. China played a leading role, sponsoring a process to gain observer status for the SCO in the UN and a resolution at the General Assembly on UN-SCO cooperation. ${ }^{116}$ The scope of the organization's goals broadened significantly to encompass counterterrorism efforts aimed at curbing extremism as well as regional economic initiatives and energy cooperation. It is not, however, a military alliance or directed against extraregional threats, which enabled India and Pakistan to join the organization in 2017.

The SCO operates via several core structures: annual head-of-state summits, more frequent meetings among foreign ministers, the Regional Anti-Terrorism Structure (RATS), and a Secretariat. It has recently begun cooperating in joint exercises to combat cyber terrorism. ${ }^{117}$ However, the independent power of this institutional infrastructure is questionable at best. Most observers have been skeptical of its achievements. One scholar views the SCO as no more than a "weak multilateral framework" for coordinating regional policies between its members, questioning its efficacy as an autonomous body in its own right. ${ }^{18} \mathrm{He}$ argues that most of the deals and initiatives brokered under its auspices consist of bilateral deals that probably would have happened even if the SCO never existed; the SCO provides only a "convenient negotiating venue." 119 Others deride the SCO as "more of a private club" than a competent multilateral body and "more form than substance." 120

The organization's most prominent public events, like the annual summits and joint military exercises, are paid for by member states directly. ${ }^{121}$ Thus, the SCO does not possess any meaningful financial autonomy from its member states, which often foot the bill for organizational activities.

\footnotetext{
${ }^{116}$ Cooperation Between the United Nations and the Shanghai Cooperation Organization, adopted November 11, 2014, UN Doc. A/RES/69/11.

${ }_{117}$ SCO Anti-Cyber-Terrorism Drill Held in China, SHINE (Dec. 12, 2019), at https://www.shine.cn/news/ nation/1912127885/.

${ }^{118}$ Richard Weitz, The Shanghai Cooperation Organization (SCO): Rebirth and Regeneration? - Analysis, EURASIA Rev. (Oct. 10, 2014), at http://www.eurasiareview.com/10102014-shanghai-cooperation-organization-scorebirth-regeneration-analysis.

${ }^{119}$ Richard Weitz, The Shanghai Cooperation Organization: A Fading Star?, Asan F. (July-Aug 2014), at http:// www.theasanforum.org/the-shanghai-cooperation-organization-a-fading-star.

${ }^{120}$ Amit R. Saksena, The Shanghai Cooperation Organization and Central Asian Security, Diplomat (July 25, 2014), at https://thediplomat.com/2014/07/the-shanghai-cooperation-organization-and-central-asian-security; Weiqing Song, Interests, Power and China's Difficult Game in the Shanghai Cooperation Organization (SCO), 23 J. Contemp. China 85 (2014), available at https://www.tandfonline.com/doi/abs/10.1080/10670564.2013. 809981.

${ }^{121}$ David Suter, China Forging International Law: The SCO Experience, Diplomat (Sept. 7, 2014), at https:// thediplomat.com/2014/09/china-forging-international-law-the-sco-experience.
} 
While the institutional structure of the SCO is ultimately quite weak, leaving much room for the individual interests of its member states to take precedence, it has played a role in the normative development of authoritarian international law in its active identification of the "three evils" - terrorism, separatism, and extremism — as targets for cross border cooperative repression. These will be elaborated in the next Part. The SCO has also introduced a subtle rhetorical shift in focusing on the "rule of international law," which reinforces sovereignty and consent, rather than the thicker concept of the international rule of law pushed by some democracies. ${ }^{122}$ The latter phrase implies extending rule of law values- accountability, equality, and fairness - to the international level. ${ }^{123}$ The rule of international law instead emphasizes traditional Westphalian values such as the faithful observance of international norms.

One of the international law innovations of the SCO is that some of its norms are supposed to guide the member states' behavior with respect to other treaties. ${ }^{124}$ As a general matter, the SCO does not impose substantive constraints on the ability of its member states to join other international legal instruments and organizations, rendering its own authority over its members quite weak and leaving them free to participate in other treaty regimes. The SCO conflict clause, for example, states that in the event an obligation imposed by an SCO document conflicts with a provision in another international treaty, the provisions in the other treaty take precedence. However, there is an exception that prohibits parties from concluding other treaties that run counter to the SCO treaties; these clauses appear most frequently in SCO treaties concerned with the "three evils" of terrorism, separatism, and extremism. ${ }^{125}$ This suggests that a treaty that sought to recognize, for example, a claim of secession by a member's substate would be void under the terms of the SCO treaties.

By enhancing domestic and cross-border security cooperation, the SCO allows its member states to reduce the possibility of regime change and to bolster authoritarian principles through multilateral cooperation. ${ }^{126}$ This rhetoric is partly defensive, a way of combating the threat of democracy-promotion by delegitimizing democratic principles. ${ }^{127}$ Democracy is not mentioned, however, so the SCO does not fall into the category of pure mimicry. Instead, by emphasizing the value of stability and pluralism, the SCO can be understood as a way for its member states to shore up the legitimacy of their authoritarian regimes and insulate them from democratization pressures.

As in many treaties among authoritarian regimes, and consistent with the theory laid out in Part II, there is no delegation to a third party to resolve disputes in SCO agreements. Instead,

${ }^{122}$ See, e.g., Dushanbe Declaration of Chapters of State Members of the Shanghai Cooperation Organization, Aug. 28, 2008, available at https://cis-legislation.com/document.fwx?rgn=24177; Bardo Fassbender, What's in a Name? The International Rule of Law and the United Nations Charter, 17 CHINESE J. INT'L L. 761 (2018) (describing evolution of thicker concept of rule of law.)

${ }^{123}$ See, e.g., GA Res. 67/1 Declaration of the High-level Meeting of the General Assembly on the Rule of Law at the National and International Levels, para. 2 (adopted Sept. 24, 2012); Edric Selous, The Rule of Law and the Debate on it in the United Nations, in The Rule of LaW and Its Application to the United Nations 13 (Clemens A. Feinäugle ed., 2016).

${ }^{124}$ Suter, supra note 121.

${ }^{125} \mathrm{Id}$.

126 Thomas Ambrosio, Catching the "Shanghai Spirit": How the Shanghai Cooperation Organization Promotes Authoritarian Norms in Central Asia, 60 EUR.-AsIA STUD. 1321 (2008).

${ }^{127}$ Id. 
the preferred approach to dispute resolution is negotiation and consultation. This facilitates coordination by executives.

The pattern of norm-building activity in the SCO will sometimes fall in a sequence, with a "concept" followed by a "program," followed by a "plan," with each iteration becoming more detailed in the cooperation that is required. The instruments are also notable for referring to UN documents, such as General Assembly Resolutions. This is part of a growing strategy by leading authoritarian nations to engage with the UN machinery, along with other international organizations such as the Commonwealth of Independent States and the Collective Security Treaty Organization. In this sense, the SCO is projecting regional norms onto a broader international arena, contributing to more global normative development.

\section{The SCO as Harbinger}

The SCO can be considered a critical step in the development of authoritarian international law in the twenty-first century in another respect-it has served a vehicle for China to test its own approach. Some analysts have argued that the SCO has been hampered by the geopolitical competition between its two most powerful members, Russia and China. ${ }^{128}$ Still, there is much common ground between Russia and China on the nature and use of international law. In 2016, the two countries issued a joint Declaration on the Promotion of International Law. ${ }^{129}$ This statement reaffirmed the traditional touchstones of sovereignty and nonintervention, such as the Five Principles of Peaceful Coexistence, the UN Charter, and the 1970 Declaration on the Principles of International Law Concerning Friendly Relations and Cooperation Among States. ${ }^{130}$ While committing to the peaceful settlement of international disputes, the Declaration reaffirms the importance of consent and good faith, a position that "applies equally to all types and stages of dispute settlement." 131 One might read this as requiring specific consent to each instance of dispute resolution. It also specifically mentions UNCLOS and the requirement of consistent application of its provisions, "in such a manner that does not impair rights and legitimate interests of States Parties"132 — a veiled reference to the South China Sea Arbitration that was ongoing at the time and to which China never gave specific consent over ITLOS jurisdiction. ${ }^{133}$ The statement also condemns terrorism, unilateral sanctions, and coercive measures outside the context of the Security Council process, and reaffirms state immunity.

Though sounding in classical Westphalian sovereignty, the Russia-China statement is in fact more sophisticated and reflects a good deal of learning and experimentation by authoritarian leaders toward extending their own rule and reinforcing each other. A changing balance

\footnotetext{
${ }^{128}$ Michael Fredholm, Too Many Plans for War, Too Few Common Values: Another Chapter in the History of the Great Game or the Guarantor of Central Asian Security?, in THE SHANGHAi Economic CoOPERATION AND Eurasian Geopolitics 16 (Michael Fredholm \& Birgit N. Schlyter eds., 2013); Weitz, supra note 119.

129 The Declaration of the Russian Federation and the People's Republic of China on the Promotion of International Law, June 25, 2016, available at https://www.lawfareblog.com/text-russia-china-joint-declaration-promotion-and-principles-international-law.

${ }^{130} I d$., para. 1.

131 Id., para. 5.

132 Id., para. 9.

133 The Republic of the Philippines v. The People's Republic of China, PCA 2013-19. Indeed the decision in that case was issued only two weeks later.
} 
of power in favor of authoritarians will give these countries greater weight in the formation of international law generally, as well as the ability to deploy specific strategies within the field.

China, in particular, will have an outsized role, given the size of its economy and its global ambitions under President Xi Jinping, who has emphasized “win-win” (共赢- “gong ying”) foreign policy, "mutually beneficial cooperation," and "a Community of Shared Future for Mankind." ${ }^{134}$ China is promoting these concepts in its increasingly assertive role in international organizations, especially the United Nations, where it is embedding its ideas into resolutions and initiatives. ${ }^{135}$ This more active multilateralism coincides with China becoming "increasingly flexible toward the Westphalian norms of state sovereignty and non-intervention." 136 China is also more prepared to redefine its interests and accept costs, except in matters related to human rights, humanitarian intervention, and self-determination, which could threaten domestic regime stability. ${ }^{137}$

It is not only at the level of rhetoric in which authoritarians are softening their Westphalian stance. One way in which Russia and China have moved beyond the noninterference principle is their increasingly complex strategies of supporting "rabble-rousing" inside other countries. ${ }^{138}$ These activities includes election manipulation, creating "fake news," and espionage. ${ }^{139}$ Authoritarians also use international organizations to provide direct support for authoritarian allies in neighboring countries. When Daniel Ortega was consolidating his control of the Nicaraguan political system in the run-up to elections in 2015, he borrowed several strategies from Hugo Chávez but also obtained support from the Bolivarian Alliance for the Americas (ALBA), which invested funds in a Nicaraguan television station to ensure its support for Ortega. ${ }^{140}$ The legal framework of ALBA facilitated the undermining of a free press in a hotly contested election.

These activities of cooperating for mutual support and interfering in the internal affairs of other countries, however, do not address the content of authoritarian international law, as distinct from pro-democratic or regime-neutral international law. The next Part of this Article turns to nascent normative developments pushed by authoritarian regimes.

${ }^{134}$ CAI, supra note 53, at 324-26.

${ }^{135}$ A New Battleground, Economist, Dec. 7, 2019, at 41.

${ }^{136}$ Yin He, China's Changing Policy on UN Peacekeeping Operations, 69 (Stockholm: Institute for Security and Development Policy, 2007), available at http://isdp.eu/content/uploads/publications/2007_he_chinas-changingpolicy.pdf.

137 Ann Kent, China's International Socialization: The Role of International Organizations, 8 GLOB. GOVERNANCE 343 (2002).

${ }^{138}$ Hendrick Talley \& Asaf Lubin, The International Law of Rabble-Rousing, 45 YALE J. INT'L L. OnLINE (forthcoming); Björnstjern Baade, Fake News and International Law, 29 Eur. J. INT'L L. 1357 (2018); Barrie Sander, Democracy Under The Influence: Paradigms of State Responsibility for Cyber Influence Operations on Elections, 18 Chinese J. InT'L L. 1 (2019); Duncan Hollis, The Influence of War; the War for Influence, 32 TEMP. INT'L \& Comp. L.J. 31 (2018); Jens David Ohlin, Did Russian Cyber Interference in the 2016 Election Violate International Law, 95 Tex. L. Rev. 1579 (2017); Oisin TANsey, InTERnational Politics of Authoritarian RulE 128 (2016).

${ }^{139}$ It is unclear whether such interference violates the proscription against coercive intervention, laid out by the ICJ. Military and Paramilitary Activities in and Against Nicaragua (Nicar. v. U.S.), Merits, 1986 ICJ Rep. 14, 108 (June 27) ("intervention is wrongful when it uses methods of coercion" and "the element of coercion ... defines, and indeed forms the very essence of, prohibited intervention")

${ }^{140}$ Rachel Vanderhill, Promoting Authoritarianism Abroad 104 (2016). 


\section{Beyond Westphalia: The Content of Authoritarian International LaW}

This Part offers three examples of ways in which a growing authoritarian role in the international arena may affect the normative content of international law: the development of new norms to facilitate internal repression, regulation of cyberspace, and the dilution of democratic concepts and institutions. These examples are illustrative, not exhaustive, but they give a flavor of the directions authoritarian international law might take.

\section{New Norms: Extremism and Separatism}

Of the organizations surveyed in Part IV, the SCO has been the most advanced in articulating new international norms, particularly in its elaboration of the "three evils" discussed above - terrorism, separatism, and extremism. These terms received further elaboration in a SCO Convention on Countering Terrorism, Separatism and Extremism of 2001 (which entered into force in 2003), and subsequent instruments. ${ }^{141}$ The definition of terrorism largely mimics the global definition elaborated in numerous multilateral treaties, but separatism and extremism are new concepts on the international plane. ${ }^{142}$ Separatism refers to any act to violate territorial integrity or directed at state disintegration. ${ }^{143}$ Extremism is defined as "an act aimed at seizing or keeping power through the use of violence or changing violently the constitutional regime of a State, as well as a violent encroachment upon public security, including organization, for the above purposes. ..."144 The term has been invoked recently, for example, with regard to the demonstrators in Hong Kong. ${ }^{145}$

A separate Convention on Counter-Terrorism was adopted in 2009, and a Convention on Countering Extremism was signed in June 2017. ${ }^{146}$ Both of these more specific treaties expand the relevant definitions of these concepts, extending them beyond "acts" to include "ideology and practice." Both commit states to criminalize, punish, and cooperate in the prosecution of violators, along the lines of the various global treaties on terrorist acts. ${ }^{147}$

${ }^{141}$ Shanghai Convention on Combating Terrorism, Separatism and Extremism, June 15, 2001 (entered into force Mar. 29, 2003).

${ }^{142}$ The 2001 Convention defines "terrorism" as "any act recognized as an offence in one of the treaties listed in the Annex to this Convention (hereinafter referred to as "the Annex") and as defined in this Treaty; b. other act intended to cause death or serious bodily injury to a civilian, or any other person not taking an active part in the hostilities in a situation of armed conflict or to cause major damage to any material facility, as well as to organize, plan, aid and abet such act, when the purpose of such act, by its nature or context, is to intimidate a population, violate public security or to compel public authorities or an international organization to do or to abstain from doing any act, and prosecuted in accordance with the national laws of the Parties."

${ }^{143}$ Separatism is "any act intended to violate territorial integrity of a State including by annexation of any part of its territory or to disintegrate a State, committed in a violent manner, as well as planning and preparing, and abetting such act, and subject to criminal prosecuting in accordance with the national laws of the Parties." Shanghai Convention on Combating Terrorism, Separatism and Extremism, Art. 1(2).

${ }^{144}$ Id. Art. 1(3).

145 Joyce Y.M. Nip, Extremist Mobs? How China's Propaganda Machine Tried to Control the Message in the Hong Kong Protests, CONVERSATION (July 15, 2019), at http://theconversation.com/extremist-mobs-how-chinas-propaganda-machine-tried-to-control-the-message-in-the-hong-kong-protests-119646. Note that the SCO's stance on Hong Kong has been to call for noninterference in a domestic Chinese matter. SCO Secretary-General Issues Statement on HKSAR, CHINA Daily (Sept. 24. 2019), at https://www.chinadaily.com.cn/a/201909/24/ WS5d89aa4ca310cf3e3556d275.html.

${ }^{146}$ Convention of the Shanghai Cooperation Organization Against Terrorism, June 16, 2009; Convention of the Shanghai Cooperation Organization on Combating Extremism, June 9, 2017.

${ }^{147}$ Id. 
Cooperation to counter extremist financing is also included in the latest treaty. Together they form the basis for joint SCO action against "societal radicalization."148

These norms represent an evolution from existing law. Criminalizing advocacy of separatism is in some tension with the international norm of self-determination, as traditionally understood. That norm does not generally provide a right to external self-determination in the form of secession. ${ }^{149}$ But many argue that it includes an exception in instances of severe oppression of rights to internal self-determination, a position given some support by the Supreme Court of Canada in its decision on Quebec's secession referendum. ${ }^{150}$ The ICJ's cautious advisory opinion in the Kosovo case refrained from specifically endorsing this exception. ${ }^{151}$

At a moment of heightened demands for secession around the world, the SCO norm against separatist ideology on a regional level has important implications. It demonstrates that states may go quite far in punishing freedom of expression if it is designated as "secessionist," which in turn hampers the ability of an oppressed group to raise awareness of their conditions to the international plane. This may undermine the consolidation of the "oppression exception" articulated by the Supreme Court of Canada and affirmed by advocates of the Kosovo Declaration of Independence.

Extremism, too, is a new and vague term. To introduce it implies a separate "evil" not currently covered by terrorism or separatism. Thus, extremism goes beyond acts of violence directed at changing state policy, as those would fall under conventional definitions of terrorism. The explicit focus on "seizing or keeping power" suggests that it is narrowly targeted at violent political action directed at state authorities. While there is surely a difference between peaceful mobilization for democratic change and violent action, the line is fuzzy in the context of an authoritarian regime. One might imagine that demonstrations such as those that recently triggered constitutional change in Chile or Panama, which were by and large peaceful but did involve some violent elements, would trigger wholesale repression, mutually supported by neighbors, were they to occur in an SCO country. ${ }^{152}$

The pattern evidenced with the "three evils" is one of normative experimentation, extending an existing model and tools to a new concept. The new norms help ensure that member countries will not provide safe havens for dissidents from other countries, and have led to concrete cooperation to enhance security. One example occurred after the July 2009 riot in Urumqi, Xinjiang, in which SCO members successfully cooperated to quell a security threat: Kyrgyzstan detained the organizers of the anti-China protest, and Kazakhstan and

${ }^{148}$ Rashid Alimov, The Role of the Shanghai Cooperation Organization in Countering Threats to Peace and Security, UN CHRONICLE, at https://www.un.org/en/chronicle/article/role-shanghai-cooperation-organizationcounteracting-threats-peace-and-security [visited Nov. 1, 2019].

149 Antonio Cassese, Self-Determination of Peoples: A Legal Reappraisal (1999)

${ }^{150}$ Reference by the Governor in Council Concerning Certain Questions Relating to the Secession of Quebec from Canada ([1998] 2 Supreme Court Reporter (SCR) 217; 161 Dominion Law Reports (DLR) (4th) 385; 115 ILR 536).

${ }^{151}$ Accordance with International Law of the Unilateral Declaration of Independence in Respect of Kosovo, Advisory Opinion, 2010 ICJ. Rep. 403 (July 22).

152 Police Clear Protestors from Panama's Congress, AP News (Oct. 29, 2019), at https://apnews.com/e797b5febaf744228ad64befaeeb163a; John Bartlett, "The Constitution of the Dictatorship Has Died": Chile Agrees Deal on Reform Vote, Guardian (Nov. 15, 2019), at https:/www.theguardian.com/world/2019/nov/15/chile-referendum-new-constitution-protests. 
Russia extradited fleeing suspects and dissidents at China's behest. ${ }^{153}$ SCO members now share information on each other's opposition groups, using extradition and denials of asylum to facilitate politically motivated prosecution and repression. ${ }^{154}$

These extradition practices implicate the political offense exception in international extradition law, which is found in many bilateral extradition treaties. The exception arose in the nineteenth century, in part as a way for states to avoid having to make case-by-case judgments about whom to extradite. ${ }^{155}$ Extraditions of a regime's political opponents, it was thought, might "embroil the requested State in the domestic politics of the State requesting extradition." 156 The exception is sometimes characterized as reflecting the idea that political offenses are motivated by a desire to benefit society, rather than for personal motive, but was predominately promoted and implemented by liberal states, which did not want to cooperate with illiberal states in repressing dissidents. ${ }^{157}$ This norm might thus be characterized as leaning toward "democratic international law" in that it facilitated freedom of political expression to advocate for change in other states. (One exception from early on, however, applied to anyone who had attempted to assassinate a head of state; such actions frequently have been excluded from the scope of the political exception.)

In the late twentieth century, some bilateral extradition treaties began to exclude from the scope of the political exception anyone whom both states were required by a multilateral treaty to extradite. ${ }^{158}$ This means that in practice, there is no exception to extradition for those whose crimes include acts of genocide, war crimes, and terrorism, or any other violation for which an international convention has a specific prosecute-or-extradite regime.

The SCO treaties neatly exploit this multilateral treaty exclusion for authoritarian cooperation. With international "evils" now including new, vague crimes of separatism and extremism, the treaties expand the set of actors whose "political" behavior would nevertheless render them available for extradition under bilateral treaties. This normative development illustrates the shift in emphasis from external security threats to internal security threats as a feature of authoritarian international law.

\section{Cyberlaw Initiatives}

In November 2019, the United Nations General Assembly adopted the resolution "Countering the Use of Information and Communications Technologies for Criminal

153 Zhao Huasheng, China's View of and Expectations from the Shanghai Cooperation Organization, 53 AsIAN Surv. 436 (2013); David Ward, The Shanghai Cooperation Organization's Bid to Transform International Law, 11 BYU Int'L L. \& MGMt. R. 162 (2015), available at https:/digitalcommons.law.byu.edu/ilmr/vol11/iss2/8/.

${ }^{154}$ Counter-Terrorism and Human Rights: The Impact of the Shanghai Cooperation Organization (Human Rights in China Whitepaper, Mar. 2011).

${ }^{155}$ Vincent DeFabo, Terrorist or Revolutionary? The Development of the Political Offender Exception and its Effects on Defining Terrorism in International Law, 2 AM. U. NAT'L SEC. L. BRIEF 69, 70 (2012).

${ }^{156}$ UN Office on Drugs \& Crime, Revised Manuals on the Model Treaty on Extradition and on the Model Treaty on Mutual Assistance in Criminal Matters, at 10 (2002), available at https://www.unodc.org/pdf/model_treaty_extradition_revised_manual.pdf.

${ }^{157}$ DeFabo, supra note 155 , at 74 .

158 See, e.g., Extradition Treaty Between the United States of America and Antigua and Barbuda, Art. 4.2(b), June 3, 2019; China-Lesotho Extradition Treaty, Art. 3(1) (political offenses do not include "Criminal acts referred to in multilateral agreements to which both Contracting States are parties and are obliged to extradite or prosecute"). 
Purposes"159 by a vote of 88 to 58, with 34 abstentions. Proponents of the resolution included Cambodia, China, Iran, Myanmar, Nicaragua, Syria, and Venezuela. The United States and other Western countries opposed the resolution. ${ }^{160}$ The large number of abstentions came mainly from Latin American and African countries.

This resolution followed the Draft United Nations Convention on Cooperation in Combating Cybercrime, ${ }^{161}$ which proposed the creation of an enforcement body in the UN called the Technical Commission on Combating ICT Crime. The Draft Convention closely mimics the Council of Europe's 2001 Budapest Convention on Cybercrime, which has fifty-six signatories, but the Draft omits provisions that discuss proportionality, and has fewer references to human rights. ${ }^{162}$ It also emphasizes sovereignty and noninterference. ${ }^{163}$ And it extends its scope to new offenses, such as "unauthorized access to electronic information" as well as those defined by international treaties against terrorism. ${ }^{164}$

At the end of 2019, the United Nations created an expert group to meet in August 2020 to draft a new cybercrime treaty. ${ }^{165}$ Russia has stated that this proposed treaty is meant to be an "alternative" to the Budapest Convention. However, the United States and other governments claim that this new treaty will allow its proponents to block anti-government websites and communications by dissidents. According to some, the new proposed treaty does not focus on "hacking attacks, privacy violations, or identity thefts"; rather, the "treaty is intended to create international law that would make it easier for countries to cooperate to repress political dissent." 166 A European official claims that this treaty is "not about cybercrime," but about "who controls the internet." 167

Human rights groups have also expressed concerns about the proposed treaty. In an open letter to the General Assembly, ${ }^{168}$ they claimed that the treaty "opens the door to

${ }^{159}$ Justin Sherman \& Mark Raymond, The U.N. Passed a Russia-Backed Cybercrime Resolution. That's Not Good News for Internet Freedom, WASH. POST (Dec. 4, 2019), at https://www.washingtonpost.com/politics/2019/12/ 04/un-passed-russia-backed-cybercrime-resolution-thats-not-good-news-internet-freedom; GA Res. 74/L.11, Countering the Use of Use of Information and Communications Technologies for Criminal Purposes (Nov. 5, 2019), at https://digitallibrary.un.org/record/3831879? $1 \mathrm{n}=\mathrm{en}$.

${ }^{160}$ Sherman and Raymond, supra note 159.

${ }^{161}$ GA Res. 72/12, Draft United Nations Convention on Cooperation in Combatting Cybercrime, Oct. 16, 2017, at https://undocs.org/A/C.3/72/12.

162 Compare Convention on Cybercrime, Art. 15, available at https://www.coe.int/en/web/cybercrime/thebudapest-convention (states "shall incorporate the principle of proportionality") with Draft United Nations Convention on Cooperation in Combating Cybercrime, Art. 22, UN Doc. A/C.3/72/12) (no mention of proportionality). The Budapest Convention mentions human rights in the preamble, whereas the Draft Convention does not.

${ }^{163}$ Draft Convention, supra note 161, Art. 3.

${ }^{164}$ Id. Art. 6 (unauthorized access); Art. 17 (international treaties). The proposed draft also targets a number of practices outside the scope of the Budapest Convention, including phishing, spam, and malware.

${ }^{165}$ Edith M. Lederer, UN Gives Green Light to New Treaty to Combat Cybercrime, AP News (Dec. 27, 2019), at https://apnews.com/79c7986478e5f455f2b281b5c9ed2d15; Ellen Nakashima, U.N. Votes to Advance RussianLed Resolution on a Cybercrime Treaty, WASH. PosT (Nov. 19, 2019), at https://www.washingtonpost.com/ national-security/un-votes-to-advance-russian-led-resolution-on-a-cybercrime-treaty/2019/11/19/fb6a633e0b06-11ea-97ac-a7ccc8dd1ebc_story.html.

166 Sherman \& Raymond, supra note 159.

${ }^{167}$ Id.

${ }^{168}$ Ass'n for Progressive Communications, Open Letter to the UN General Assembly: Proposed International Convention on Cybercrime Poses a Threat to Human Rights Online (Nov. 2019), at https://www.apc.org/en/ pubs/open-letter-un-general-assembly-proposed-international-convention-cybercrime-poses-threat-human. 
criminalising ordinary online behavior . . . protected under international human rights law." ${ }^{169}$ Noting the trend in some countries to misuse cybercrime law in order to "criminalise legitimate forms of online expression, association and assembly," the open letter criticized the retreat from the protections offered by the Budapest Convention, and urged the improvement of current legal frameworks rather than the creation of a new treaty.

Observers claim that the proposed treaty demonstrates "decreased support for an open internet." 170 Additionally, this treaty proposal demonstrates how "authoritarian governments have become more adept at turning multilateral diplomacy toward their own ends." 171 Observers describe this as an example of "authoritarian multilateralism," which is the "use of ostensibly liberal-democratic multilateral institutions to advance illiberal agendas and values." 172

\section{Repurposing Democratic Tools and Language}

Another feature of authoritarian international law is the concerted effort to neutralize multilateral forums as vehicles for democracy promotion. The capture of the Human Rights Council is a well-known example, as authoritarian states have effectively neutralized the requirement of the 2006 reforms that countries have a strong human rights record in order to serve on the Council. Current authoritarian members as of this writing include Bahrain, Cuba, Qatar, Rwanda, and Saudi Arabia, among others.

Data gathered from the UN Human Rights Resolution Portal also indicates that authoritarian states, including Cuba, China, and Venezuela, are more frequently sponsoring resolutions. ${ }^{173}$ Such states constituted some 45 percent of the "main sponsors" of resolutions in 2018-2019, up from 30 percent in 2009. ${ }^{174}$ For example, China introduced a resolution, "Promoting the International Human Rights Cause Through Win-Win Cooperation," to advance its signature rhetorical approach. A study of China's voting pattern finds that its "fundamental goals" are "to shield itself and others from criticism and undermine the ability of the international human rights system to monitor and investigate violations." 175 China-sponsored resolutions seek to undermine the power of civil society, delegitimize human rights defenders, and advance China's goal to deflect scrutiny of its human rights record. ${ }^{176}$

China also seems committed to repurposing the language of democracy. In September 2019, China's State Council issued a white paper on China and the World in the New Era that emphasizes China's democratic credentials and argues for "democratic international relations" while promising that the country "will remain committed to multilateralism, uphold international equity and justice, and work with other countries to promote

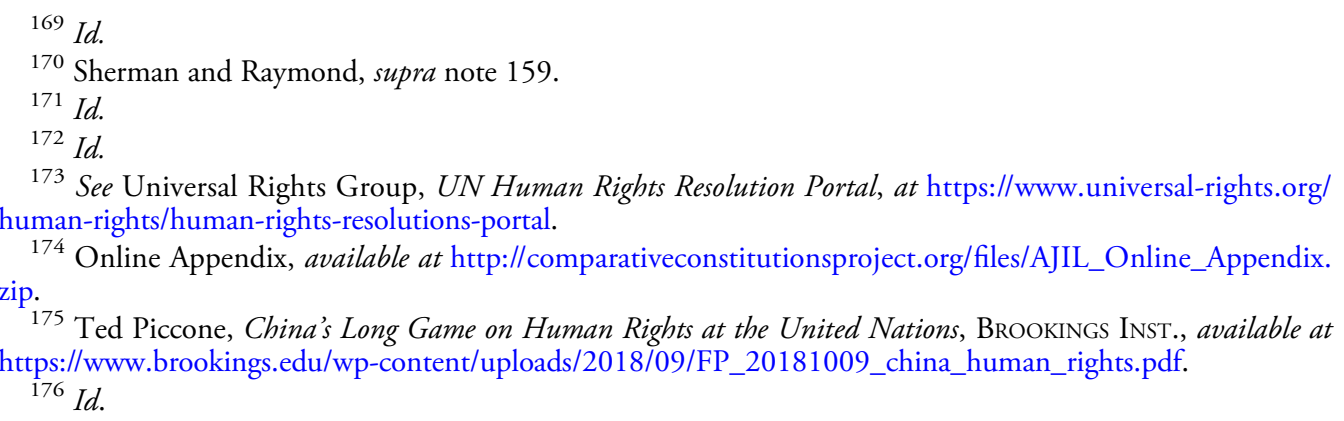


democracy, the rule of law and a proper balance in international relations." 177 The statement can be read as muddying the normative content of the term democracy itself, putting "socialist democracy" on equal footing with other conceptions that involve actual competition for power.

Other authoritarians are repurposing the machinery of democracy promotion-one of the pillars of Franck's evidence for a "right to democracy" - for autocratic entrenchment. There has been a rise of alternative election monitoring through authoritarian international organizations that certify dubious elections, muddying the informational quality of democracy-promoting election monitors. ${ }^{178}$ The Commonwealth of Independent States has played a leading role here, both on its own and through a related nongovernmental organization, the Commonwealth of Independent States Election Monitoring Organization. These bodies regularly certify elections in its area of operation. Their criteria for doing so emphasize "country-specific" variables, a kind of legitimation for less than democratic standards. They almost always certify elections as "free and fair," including in such egregious dictatorships as Turkmenistan. ${ }^{179}$ In the Kyrgyz parliamentary elections of 2007, the CIS and the SCO established their own election observers, certifying the credibility of an election that was criticized by the monitors from the more democracy-grounded Organization for Security and Co-operation in Europe (OSCE). ${ }^{180}$ Venezuela has had the Union of South American Nations (UNASUR), rather than the more established OAS, monitor its elections on several occasions. ${ }^{181}$ These so-called "zombie" election monitors is an example of authoritarian mimicry of form without function. ${ }^{182}$

\section{What Is NeW and What Is Not}

As the discussion of regional organizations in Part IV demonstrates, authoritarian states have always used international law to advance particular ends. But, consistent with the existing literature, this cooperation among authoritarians has been shallow and weakly institutionalized. The post-Cold War period has seen a gradual shift toward more sophisticated forms of cooperation. As regimes such as those in China and Russia have withstood pressures for liberalization, they are able to experiment with their use of international law, and even able to put forward new norms that I am characterizing as authoritarian international law.

The shifts laid out in this Article are subtle and not sharp. Indeed, authoritarian international law is a good example of what scholars of institutional change call "layering." 183 All

177 State Council, China and the World in the New Era, at 38 (Sept. 2019).

178 Patrick Merloe, Authoritarianism Goes Global: Election Monitoring vs. Disinformation, 26 J. Dem. 79 (2015); Christopher Walker, The Authoritarian Threat: The Hijacking of "Soft Power," 27 J. Dem. 49 (2016); Lee Morgenbesser, Fake Monitors Endorse Cambodia's Sham Election, For. POL'y (July 30, 2018), at https://foreignpolicy.com/2018/07/30/fake-monitors-endorse-cambodias-sham-election.

179 OBYDENKOVA \& LiBman, supra note 60, at 162-64.

180 Alexander Cooley, The League of Authoritarian Gentlemen, For. POL'y (Jan. 30, 2013), at https://foreignpolicy.com/2013/01/30/the-league-of-authoritarian-gentlemen.

${ }^{181}$ Morgenbesser, supra note 178.

${ }^{182}$ Christopher Walker \& Alexander Cooley, Vote of the Living Dead, For. POL'y (Oct. 31, 2013), at https:// foreignpolicy.com/2013/10/31/vote-of-the-living-dead; Judith G. Kelley, Monitoring Democracy: When International Election Observation Works, and Why It Often Fails (2012).

${ }^{183}$ Jeroen van der Heijden, Institutional Layering: A Review of the Use of the Concept, 31 POL. 9 (2011). 
international orders build on the structure that come before, and today's authoritarian turn is no exception. Neither Russia nor China are setting out to build an alternative model to the Western international law scheme, or to replace institutions or legal regimes such as the WTO, investment law, and the protection of intellectual property. Instead, they seem to be seeking to utilize existing structures to their own ends, as would any powerful country. The model is one of sedimentation, with a new layer of ideas, rhetoric, and institutions resting on top of the prior one. ${ }^{184}$

Yet, when viewed in the aggregate, the contrast with the liberal model of international law that was dominant in the 1990s is stark. Instead of deep, sovereignty-eroding regional integration, with extensive delegation to international organizations, we see thinner models of cooperation that demand little of members and can be discarded once their political purpose has been served. Examples here include the ALBA, which withered after the death of Hugo Chávez, and the Gulf Cooperation Council (GCC), established by six Arab Gulf states in 1981, in part as a response to the Iranian Revolution. The GCC promoted economic and security cooperation, and helped to shore up the monarchy of Bahrain during the Arab Spring, but has now become essentially dormant because of intraregional tensions involving Qatar.

Instead of third-party dispute resolution, we are observing a softer "dialogue and mutual respect" framework that is less rule-bound and more focused around negotiated solutions to international problems. Many of the instances of backlash against international tribunals, or "dejudicialization" of policy areas, are initiated by authoritarian states. ${ }^{185}$ For example, in the various commentary on withdrawal from the International Criminal Court (ICC), it is worth noting that every case of threatened or actual withdrawal from jurisdiction was by an authoritarian government, such as Paul Kagame's Rwanda, or a rapidly backsliding one, such as in the Philippines under Rodrigo Duterte or South Africa under Jacob Zuma. ${ }^{186}$ (To be sure, democratic institutions have held in South Africa, which revoked its withdrawal and so remained in the ICC; Zuma is now under indictment.)

Accompanying weaker dispute resolution is an emphasis on softer commitments and dialogue. Iterated negotiation allows power to be exercised behind the veneer of win-win rhetoric. And instead of a logic of commitment and hands-tying, international law plays a thinner, coordinating role. The goal is not to tie states' hands across generations, but instead to facilitate cooperation by leaders who need flexibility more than commitment.

${ }^{184}$ G. John Ikenberry \& Darren Lim, China's Emerging Institutional Statecraft: The Asian Infrastructure Investment Bank and the Prospects for Counter-hegemony, BROOKINGS InST. (Apr. 2017), at https://www.brookings.edu/research/chinas-emerging-institutional-statecraft.

185 See Karen Alter, James T. Gathii \& Laurence R. Helfer, Backlash Against International Courts in West, East and Southern Africa: Causes and Consequences, 27 Eur. J. InT'L L. 293 (2016); Mikael Rask Madsen, Pola Ceublak \& Micha Weibusch, Backlash Against International Courts: Explaining Resistance to International Courts, 14 INT'L J. L. Context 197 (2018); Daniel Abebe \& Tom Ginsburg, The Dejudicialization of International Politics?, 63 InT'L STUD. Q. 521 (2019); Tendayi Achiume, The SADC Tribunal: Socio-political Dissonance and the Authority of International Courts, in How Context Shapes the Authority of InTERnational Courts (Karen J. Alter, Laurence R. Helfer \& Mikael Rask Madsen eds., 2017); but see Laurence R. Helfer, Overlegalizing Human Rights: International Relations Theory and the Commonwealth Caribbean Backlash Against Human Rights Regimes, 102 Colum. L. Rev 1832 (2002) (democratic countries leading backlash).

${ }^{186}$ Kamari M. Clarke, Abel S. Knottnerus \& Eefje De Volder, Africa and the ICC: Perceptions of Justice (2016); see also Thomas Gerald Daly \& Micha Wiebusch, The African Court on Human and Peoples' Rights: Mapping Resistance Against a Young Court, 14 InT'L J. L. ConTeXT 102 (2018). 
At the same time, as global power shifts toward authoritarian countries, this Article has argued that the shift away from liberal international law will not stop with a "return" to traditional Westphalian principles. Instead, I have speculated that authoritarian states will play an increasingly important role in articulating norms that will both insulate them from external pressures to liberalize, and also to consolidate internal control through cross-border cooperation. Authoritarians learn and repurpose institutions toward their own ends, and international law is no exception. The examples of diluting democratic norms, undermining democratic opposition through cyberlaw regulation, and naming new phenomena such as extremism are all evidence of a trajectory of authoritarian international law that may deepen should current governance trends continue.

There are limits to what we can observe from formal norms and institutions, and this has not been a study of the relative efficacy of or compliance with different kinds of international law. But this Article has identified several examples of effective authoritarian use of international law, as well as examples of innovation and impact on international law.

\section{Conclusion}

In concluding, let us briefly consider the normative implications of authoritarian international law, both for the world and for our understanding of international law. First, the concept highlights the quaintness of certain analyses of the 1990s, particularly those that argued that the European Union would somehow become the future of global governance. ${ }^{187}$ As Slaughter and Burke-White put it, "The Treaty of Westphalia . . . has given way to the Treaty of Rome." 188 Europe, we were told, had given up the retrograde nation-state ideology in place of a technocratic super-state of ever-widening scope. The strong implication was that where Europe would go, the world would follow, once sufficiently enlightened.

This claim was problematic on several levels, and subject to wide criticism even at the time. ${ }^{189}$ It assumed that liberal states were compliant with international norms, an assumption undermined by the phenomenon of "hegemonic international law" as practiced by the United States. ${ }^{190}$ It was incompatible with Asian economic trajectories and the region's approach to international law. ${ }^{191}$ It failed to anticipate the rise of authoritarian regimes in a global capitalist system. And, as has long been recognized, the liberal international order has interventionist tendencies that may be in fact be conflict-generating.

Liberal international relations theory, it seems, will have little relevance under authoritarian international law: integration will be shallower, agreements will be thinner, and courts will play a relatively smaller role. One of the core ideas of liberal theory, the need to look under the hood of nation states to understand the domestic interests at stake, will make less sense in an

\footnotetext{
187 Anne Marie Slaughter \& William W. Burke-White, The Future of International Law is Domestic (Or, the European Way of Law), 47 Harv. InT'L L.J. 327 (2006); Mark LeOnard, Why Europe Will Run the 21st Century 43-46 (2005).

188 Slaughter and Burke-White, supra note 187, at 331.

${ }^{189}$ José Alvarez, Do Liberal States Behave Better? A Critique of Slaughter's Liberal Theory, 12 Eur. J. INT'L L. 183 (2001).

${ }^{190}$ Vagts, supra note 50.

191 Tom Ginsburg, Eastphalia as the Perfection of Westphalia, 17 InD. J. GLob. LEG. STUD. 27 (2010).
} 
authoritarian-dominated world which will, in many ways, bring back the state. Within national constitutional orders, executives will be the leaders who Beijing and Moscow talk to. Like the era of nineteenth century espousal, states will mediate the interests of individuals and interest groups. As China, in particular, extends its economic reach by cooperating with dominant executives, it may reinforce the spread of authoritarianism in a reciprocal way. Cooperation in the Belt and Road Initiative tends to reinforce executive power, as China look for stable partners who can deliver. Private contract among state-owned enterprises will be a more desirable and flexible channel of cooperation in the economic sphere. And global civil society may matter less than ever.

One prediction of liberal theory, however, may retain relevance: that international law functions differently among different kinds of states. This Article has focused heavily on regional organizations, and there is the possibility that regional norms of an authoritarian character will remain regional, deepening the fragmentation of international law. Fragmentation may also occur across regime types, with liberal international law prevailing among liberal states, and authoritarian international law among authoritarians. But there is another possibility as well. Returning to the three categories of international law laid out in Table 1, we might expect that as authoritarian international law expands, it could be accompanied by a retreat of democracies from the pro-democratic international norms that have recently been ascendant. We certainly observe an increasing emphasis on sovereignty among some democracies, including the United States and United Kingdom, with regard to security, trade, and borders. This may indicate less willingness to invest resources in the promotion and support of democracy abroad.

The consequences for the practice of international law itself, the middle category in Table 1, are predictable but troubling: less emphasis on human rights, more dilution of democratic practices, and some evolution of economic law, in particular to address new instruments and modes of cooperation that will span the public-private divide. ${ }^{192}$ These innovations may undermine democracy-supporting norms of economic transparency.

The trend toward "good governance" regimes, pushed by Western institutions and civil society, has little utility for an authoritarian trying to consolidate control. Public-regarding procedural rules might be attractive in the economic sphere, but not in cases involving security. Classical public international law, concluded between states, will take on a softer form with less intrusive reliance on third-party dispute resolution, and more emphasis on negotiation and diplomacy. And we expect to see new norms that reflect the key concerns of authoritarian states: internal security, repression of opponents, and the maintenance of power.

The consequences for humanity are less clear. Both democratic states and authoritarians have used international law to do undemocratic things. Liberal democracies have outsourced repression of terrorists, designed systems of financial sanctions without due process, and reinforced dictators. Many would argue that general or regime-neutral international law has had an inherently authoritarian character because it insulates areas of governance from the domestic sphere. But in the end, when democratic governments reinforce autocracy abroad or cooperate across borders to lock in their particular partisan interests, they can be thrown out of power by their citizens, if those citizens are not benefitted by greater security and wealth.

\footnotetext{
${ }^{192}$ Matthew Erie, Chinese Law and Development, 62 Harv. InT'L L.J. _ (forthcoming 2020).
} 
A full normative assessment of the achievements of international law under the liberal order would involve a complex calculus, summing positive benefits for large and powerful democracies, set against sometimes-negative externalities imposed on other countries. Under a future authoritarian international order, the positive gains will be more narrowly distributed within individual countries, while the negative externalities abroad may remain the same. The normative case against authoritarian international law, then, rests partly on the idea that prodemocratic international law was a feasible project, and also on the idea that general international law has benefitted the citizens of the democracies who have played a disproportionate role in its formation since World War II. Under the liberal order, the beneficiary group of international law may have been wider than it shall be in the future, if not nearly as wide as proponents of liberalism wished it to be. 